\title{
Countermarks in the Name "Galba" on Roman Imperial and Provincial Coinages: Considerations on the Countermarks and the Circulation of Local Bronze Coins in Pannonia (?), Moesia, Thrace and Asia Minor (?)
}

\author{
Rodolfo MARTINI*
}

\section{Foreword}

From the reign of Nero to the ensuing civil wars (68-69 CE), the regions of Moesia and Thrace witnessed the widespread coining of Neronian bronze with Latin legends, typified by the 'reproduction' of certain types from the mints in Rome and Lugdunum. Especially noteworthy was the Perinthus mint, whose specimens circulated alongside local coinage with Greek legends. These issues, along with certain bronze series from the mints in Nicaea and Nicomedia, would later undergo widespread countermarking in the Danube and Asia Minor regions with countermark types using the emperor Galba's name, in both Latin and Greek lettering, either spelled out or abbreviated.

Minting order and the subsequent countermarking allow us to again take up some major questions that have arisen regarding the coinage and distribution of imperial bronze in the western part of the Empire from the time of Augustus' monetary reform onward. The complexity and multiple ramifications of this phenomenon have heretofore stymied attempts to devise an accepted, definitive explanation. Specifically, a framework is needed to comprehend the several outright local 'reruns.' Most of these are struck but a few are cast, and evidence shows they circulated daily alongside official issue, whose types they unflinchingly imitated from the central mints in Rome and Lugdunum, even while clearly bearing stylistic and morphological features that were generally inferior to their models. However, among this broad set of widespread issue various levels of production are found, with differing degrees of adherence to prototypical output from the main mints.

The reproduction of types and morphology from central coinage, in the absence of comparison based on specimens whose minting and provenance has been ascertained, often makes it complicated and speculative to clearly and assuredly separate 'official' exemplars from 'local' ones. This has led to a tendency to categorize the coins merely on the basis of portrayal, casting aside the problem of identifying their place of production, which coincides essentially with investigations into stylistic features. Stylistic inquiry has been limited because it is deemed subjective and no wholly reliable. ${ }^{1}$ Many

\footnotetext{
* Dr. Rodolfo Martini, Gabinetto Numismatico e Medagliere, Milano (rodolfo.martini@libero.it).
}

It is with great pleasure that I dedicate these notes on a class of countermarks to my colleague Johannes Nollé. The topic is evocative, harking to the most intense moments of a friendship stretching more than a score of years: lengthy exchanges of opinion, sometimes at a pitch that might have seemed sharp, over how to draw up the catalog of countermarks when publishing the Pangerl collection. My own thinking had been running in terms of mere alphabetical order but Johannes, curator of the Nomismata series, rightly saw that it ought to be ordered geographically. Once I had come wholly round to the wisdom of his reasoning and our Munich talks were winding up, they were capped by banter in a café near the Staatliche Münzsammlung over a slice of exquisite wild berry pastry.

${ }^{1}$ RPC Supplement 2, 39, no. 1762A «The rough fabric and unusual obverse legend show that this is not a coin of Rome or Lyon...». 
discussions dismiss coins whose style or morphology is 'different' out of hand, terming them "ancient forgeries" or "barbarian imitations" or "auxiliary issue" or "local copies" and so forth. The effective imperial nature of "localized" production thus often goes unrecognized and, with it, the major role played throughout the Julian-Claudian period by this huge mass of bronze coin. For this was the coin that supplied the western areas of the Empire with the small change needed for daily transactions, primarily in the context of the Legions, to be sure, but also among civilians.

Overall Julian-Claudian coin circulation, closely tied to the legionary context, was beyond any doubt affected by the widespread phenomenon of local bronze coin production. But this phenomenon is often overlooked or its actual legal nature misunderstood. Only for a few Neronian issues from around Thrace have scholars so far recognized beyond doubt the existence and distribution of these 'parallel' coinages that replicate imperial mintings. And only certain types have been so identified in Roman Provincial Coinage (RPC), usually attributed across the board to the Perinthus mint. Although many scholars have taken up the question of the production and circulation of "copies" in various regions of the Empire and included these issues among the 'provincial' operations of the Roman administration, there is as yet no framing of the phenomenon overall, nor a clear awareness, for the Julian-Claudian period, of the official status of localized bronze issue, which was rooted in the legionary context both for its production and for its use. ${ }^{2}$

The large output, high quality, obvious close ties to military administration, and the breadth of circulation of these specimens in the Danube region during Nero's time, incontrovertible evidence for which includes the considerable number of 'local' countermarked issues, not only with types relating to the emperor Galba, are phenomena that provide factors and critical inspiration to set out with fresh lean on an investigation into the production and distribution of such coin specie both for periods antedating Nero's reign and for geographic regions other than the Danube limes.

\section{Materials}

The catalog shows eight currently known countermark types (A-H) with the name "Galba," either spelled out or abbreviated, in alphabetical order, first those with legends in the Latin alphabet, then

${ }^{2}$ RPC, 320, nos. 1758-1762, Group with Latin legends and Roman types; before RIC, 186, «Uncertain (Balkan?) Mint» and 187, «[...] a semi-official aes mint [...] may have been situated in the frontier area occupied by the legions in Upper and Lower Moesia»; Howgego 1985, passim; Mac Dowall 1960, passim; Giard 1985, passim; Giard 1970, passim; Martini 2017, 236-237; Kenyon 1987, 24-26, § Contemporary imitations of the bronze coins of Claudius I; Kenyon 1992, \$ Circulation and Use of Irregular Claudian Aes, 316-328; Besombes 2003-2004, recently identifies Hispanic and Gallic mints that have coined bronze coins with Roman types during the reign of Caligula (23, «[...] un atelier provincial qui a frappé les as d'Agrippa de style non romain»; 26, «La grande nouveauté du règne de Caligula, c'est que le monnaies officielles non romaines issues d'ateliers officiels, qu'il serait difficile de localiser ailleurs qu'en Gaule [...]» and the reign of Claudius (27, «Dans la péninsule Ibérique, la production de sesterces, dupondii et as est partagée, selon nous, entre deux ateliers.»; 29, «[...] bronzes de Claude appartiennent à une production manifestement gauloise»); Kaenel 1984a, 108 «le imitazioni [...] delle province [...] coniazioni locali ufficiali oppure monete irregolarmente coniate ma in qualche modo tollerate oppure si tratta di veri e propri falsi ?» (see also Kaenel 1986, 217-218); Campo 1974, 155, «[...] no se acuñaron en la ceca oficial de Roma, sino que son producto de acuñaciones locales. No es posible creer que este tipo de moneda [...] circulara en la clandestinidad, Roma tenia que conocer forzosamente la existencia de estas acuñaciones locales [...]»; Nash 1978, 26, «Many imitations of Roman asses [...] may have been produced under official Roman supervision». 
with Greek, labeled in sequence from A to $\mathrm{H}$, followed by the GIC reference number when found on provincial coinage. The list of specimens in each group begins with Roman imperial issue, when found, followed by provincial coinage. Records for coins from the Perinthus mint follow their order in RPC, placing Greek-legend coins before those with Roman lettering. The catalog is founded on two criteria: (a) imperial issue from the mints in Rome and Lugdunum, listed in RIC order, includes all currently known specimens; (b) series minted in the provinces, ordered according to RPC, include only coins not recorded in Schönert 1965, in RPC, in Martini 2002 and 2003.

Coins for each countermark are ordered according to the criteria used in RIC and RPC, broken down by issue, identified by their catalog letter (A1...), and followed by (a) their catalog features and (b) description of the material. Information under (a) includes identification of the mint, the issuing authority, the catalog number (from RIC or RPC), the denomination by Rome-mint standards (sesterces, dupondii, asses) with certainty for the Perinthus mint and in doubt for Nicaea and Nicomedia, and a brief reminder of the reverse type. Issue identified by RPC serial number is further labeled, in brackets, by the countermark type noted in the publication for the series under consideration.

The material reviewed, (b), numbered in series, follows catalog features and references to coin (i) in public and (ii) private collections, which are identified by full last name or by the conventional monogram made up of the first two letters of place of residence and the first letter of the owner's last name, followed by the serial number and, finally, (iii) specimens that have been traded, with the name of the auction house or URL in italics. When needed to distinguish the specimen, this is followed by a brief description either of the duplicate countermarked type (e.g. [x2] in the case of GALBA) or of the co-occurrence of other countermarks. The latter are shown in boldface (e.g., NERCPP), italics (e.g., NERCPP), or plain type (e.g., GALBA), depending on whether they are still legible on the coin surface, obliterated by another countermark or represent modern forgeries, respectively. The list of material takes into consideration only coins that have been identified with certainty, thus leaving out a score of countermarked specimens for which the mint and/or reverse type cannot yet be ascertained.

Two aspects bear remarking upon prior to the catalog list. First, note the provenance of much of the recorded material. Up until the last couple decades, countermarks with the name "Galba" were rather rare, but more recently they have begun to show up with increasing regularity in auction catalogs, generally on higher-quality specimens, such as in online sales, where coins of lesser market value are shown. The nature of their provenance makes it impossible, on the one hand, to directly view the material and, on the other, provides photographic documentation at typically poor resolution, especially for online sales, which allow only low-quality images to be downloaded. As a result, complete investigation of the material is often impossible. Similarly, reproductions of coins found in private collections are often the product of cellphone photography or digital scanning, often carried out on the fly or without proper equipment (lights, tripods, etc.). This material, only rarely available for direct inspection, thus also defies positive, reliable investigation, especially when details or particular features of the devices and legends need to be taken into consideration.

In the second place, the undeniable commercial interest aroused by coins countermarked with the "Galba" name, even were it for no other reason than the historical testimony of the damnatio memoriae of Emperor Nero's figure, has encouraged the production and spread of modern forgeries, most of which use poorly preserved, original Roman imperial coins whose market value they hope to enhance by countermarking. There are also less common cases of both the coin and the countermark being forged by striking (cf. 2A.1) or casting (2B.1). 
As discussed below (v. 3.J Modern Forgeries), surefire identification of modern forgeries is complicated both by the current scarcity of countermarks with the "Galba" name, which makes type comparison fraught, and by the just-noted poor quality of so many photographic reproductions. The latter factor is further exacerbated fact that the rather rare known specimens are typically poorly preserved, both as coins and as countermarks.

\section{A. $\quad \mathbf{G A}(l b a) \mathbf{C}($ aesar $) \mathbf{P}($ ater $) \mathbf{P}($ atriae $)$}

A1. Roma, Claudius; RIC 99; sestertius, Spes

1. Brock coll., 45 (obv., GALBA + GALBA) (= CNG E126, 262)

B. GALBA (CIG, 591)

B1. Roma, Tiberius; RIC 51; sestertius, Carpentum

1. Saarbrücken, IAG (photofile) [x2] (obv., NCAPR)

B2. Roma, Tiberius; RIC 54, 60; sestertius, Quadriga (elephants)

1. DeO coll., 01 (obv., NERCPP); 2. CNG E132, 173 (obv., NERCPP)

B3. Roma, Tiberius, RIC 61,67; sestertius, Hexastyle temple

1. Cac coll., 53 (obv., NERCPP ?)

B4. Roma, Tiberius; RIC 62; sestertius, Quadriga (horses)

\section{CNG E64, 1003 (obv., NERCPP)}

B5. Roma, Nero Drusus; RIC 93, 109 (Claudius); sestertius, Curule chair

1. Budapest,MNM (gift 2000, ex Harcos coll.) (obv. NERCPP) (Harcos, Damnatio, fig. $1=$ Martini 2002, 4012); 2. Baker coll., 43 [x2] (obv., NERCPP) (=CNG 46, $1183=$ CNG 57, 1056, De Vicci coll.); 3. Baker coll., 44 [x2] (obv., NERCPP); 4. Connor coll., 09 [x2] (obv., NERCPP); $5 \mathrm{MuK}$ coll., 109 [x2]; 6. SoT coll., 05 (obv., NERCPP); 7. ancientcollectiblescoins-de, x.2011 (= Incitatus Coins), iii.2015); 8. NFA 31, 542

B6. Roma, Claudius; RIC 96; sestertius, EX SC OB CIVES SERVATOS

1. MuK coll., 109 [x2]; 2. SaM coll., 569 (obv., NERCPP); 3. SaM coll., 570 [x2]

B7. Roma, Claudius; RIC 98, 114; sestertius, Triumphal arch

1. DeO coll., 03; 2. DeO coll., 04 (obv. NERCPP)

B8. Roma, Claudius; RIC 99, 115; sestertius, Spes

1. Brock coll., 45 (obv., GACPP + GALBA) (= CNG E126, 262); 2. SaM coll., 577 (= CNG 64, 1004); 3. CNG 69, 1524 (obv., NERCPP + Nero radiate head 1.); 4. hermes-coins, iv.2006 (obv., NERCPP); 5. Rauch 80, 102 [x2] (GALBA) (cf. modern forgeries, 1C.1) + Antonia bust l. ?); 6. runtofossil, iv.2007 [x2]; 7. silenocoins, x.2007

B9. Roma, Agrippina Senior; RIC 102 (Claudius); sestertius, SC

1. Connor coll., 10; 2. Pangerl coll., TC52 [x2] (Martini 2003b, 86a) (obv., NERCPP ?); 3. CNG E183, 178 (obv., NERCPP); 4. lagalerienumismatique, xi.2004.(= Rauch Sommer 2007, 399) [x2]; 5. oldromancoins, iv.2006 (obv., NERCPP) 
B10. Roma, Claudius; RIC ---; sestertius, ---

1. BuB coll., 10; 2. BuB coll., 11 (obv., NERCPP); 3. BuN coll., 11 (obv., NERCPP); 4. CaC coll., 36 (= coloradorc, vii.2003); 5. DeO coll., 15 (obv., NERCPP) (from Sopianae area?); 6. DeO coll., 16; 7. DeO coll., 17 [x2] (obv., NERCPP) (from Sopianae area?); 8. MüP coll., 38; 9. MüP coll., 39 [x2] [NERCPP] (from Mursa?); 10. RaL coll., 31 (obv., GALBA ?) + Head r.)

Greek legends

B11. Nicaea, Nero; RPC 2050 [cmk: GALBA]; sestertius(?), Cista

B12. Nicaea, Nero / Agrippina Minor; RPC 2052 [cmk: GALBA]; dupondius(?), Dionysus

B13 Nicaea, Nero; RPC 2057 [cmk: GALBA]; dupondius(?), Cista

1. Naville Numismatics 37, 172 (Clain-Stefanelli coll.)

B14. Nicaea, Nero; RPC 2057var. [cmk: GALBA]; dupondius(?), Cista

1. SaM coll., 1646; 2. NAC R, 1444; 3. oldromancoins, iv.2005

B15. Nicaea, Nero; RPC 2060 [cmk: GALBA]; as(?), Securitas (Poppaea)

1. BuK coll., 07; 2. [viminacium]; 3. Forvm Ancient Coins, rp79840; 4. paganecoins, iii.2005

B16. Nicaea, Nero; RPC 2061 [cmk: GALBA]; as(?), Securitas (Messalina)

1. Wien,KM, 27322 (Howgego 1985, 4b)

B17. Nicaea, Nero; RPC 2060-61 [cmk: GALBA]; as(?), Securitas

1. SaM coll., 590; 2. Künker 83, 767

B18. Nicaea, Nero (head 1.); RPC 2060-61var. [cmk: GALBA]; as(?), Securitas

1. [nemonater] (= [roman]) (ex Sofia private coll.)

C. $\mathbf{G A L}(b a) \mathbf{C}($ aesar) $\mathbf{A}($ vgvstvs $)(\mathrm{GIC},-)$

C1. Roma, Claudius; RIC 96, 112; sestertius, EX SC OB CIVES SERVATOS

1. [roman] (coll. privata)

Latin legends

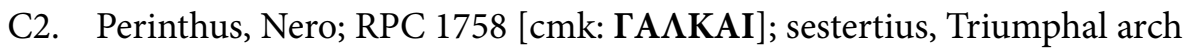

1. [roman] (private coll); 2. paganecoins_2000, xi.2003

C3. Perinthus, Nero; RPC ${ }^{\mathrm{S2}}$ 1758A [cmk: standard ? ГAAY]; sestertius, Decursio

1. Baker coll., 45 (= paganecoins, v.2002 = Martini 2003a 2, 1426); 2. Baker coll., 46 (= paganecoins, x.2001 = Martini 2003a, 1425)

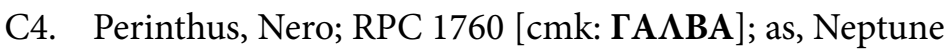

1. Brock coll. (= silenoscoins, iv.2006); 2. Savoca Coins Blue 7, part 1, 629

Greek legends

C5. Nicaea, Nero (head 1.); RPC 2057 var. [cmk: GALBA]; sestertius(?), Cista 
1. SaM coll., 584

D. Palladium $\Gamma \mathbf{A}(\lambda \beta \alpha)$ AY $(\tau o \kappa \rho \alpha ́ \alpha \omega \rho)(\mathrm{CIG}, 525)$

D1. Nicomedia, Nero; RPC 2084 [cmk: standard? TAAY]; as(?), Nike

1. Rauch Sommer 2007, 393

D2. Nicomedia, Nero; RPC 2085 [cmk: standard? TAAY]; as(?), Uncertain object

E. Palladium $\Gamma \mathbf{A} \Lambda(\beta \alpha)(\mathrm{GIC},-)$

Latin legends

E1. Perinthus, Nero; RPC ${ }^{\mathrm{S} 2}$ 1758A [cmk: standard? TAAY]; sestertius, Decursio

1. Oxford, AM (= Rauch 71, 551)

Greek legends

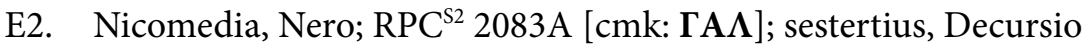

E3. Nicomedia, Nero; RPC 2086 [cmk: standard? ГAAY]; semis(?), Capricorn

F. ГА $\mathbf{B A}(\mathrm{CIG}, 526)$

Greek legends

F1. Perinthus, Nero; RPC 1752 [cmk: ГAМBA]; as, Apollo (cithara)

1. BuN coll., 05; 2. BuN coll., 19; 3. DiB coll., 15; 4. RaD coll., 08; 5. CNG 57, 783 (De Vicci coll.); 6. CNG E318, 408; 7. [curtisclay] (= CNG E320, 271); 8. CNG stock, vi.2013 (= MuM (Basel), stock 1969 (= Geranio 2014-, no. [11]); 9. hermes-coins1, ii.2003; 10. honorart, xi.2011; 11. numisart, i.2009

F2. Perinthus, Nero (head r.); RPC 1753var. [cmk: ГA $\mathbf{K}$ KII]; as, Apollo

1. Gorny \& Mosch 181, 2804 (Lot); 2. hermescoins1, xi.2003

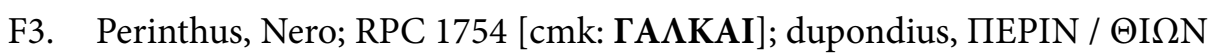

1. LoE coll., 60 (= collections57110, xi.2004)

Latin legends

F4. Perinthus, Nero; RPC 1758 [cmk: ГAМKAI]; sestertius, Triumphal arch

1. Akropolis Ancient Coins, 605

F5. Perinthus, Nero; RPC 1759 [cmk: ГAМBA]; dupondius, Securitas

1. Baker coll., 41; 2. BoP coll., 48 (= paganecoins, vi.2003); 3. WaG coll., 10

F6. Perinthus, Nero (head 1.); RPC 1759var. [cmk: standard ? ГAAY]; dupondius, Securitas

1. CNG E123, 159

F7. Perinthus, Nero; RPC 1760 [cmk: ГA $\mathbf{\text { BAA}}]$; as, Neptune

1. Baker coll., 42; 2. LoV coll., 42; 3. MoR coll., 07 ; 4. PrO coll., 14; 5. RaL coll., 16; 6. SaM coll., 583; 7. ancient-treasures, ix.2006 (= Mucelli, Contromarche, p.78); 8. Gorny \& Mosch 152, 2040 


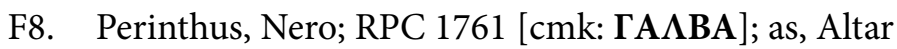

1. Brock coll., 46; 2. LoV coll., 01; 3. MoR coll., 10 (from Utus?); 4. Pangerl coll., A20 (= Martini 2003b, 92b); 5. SaM coll., 581; 6. SaM coll., 588; 7. Gorny \& Mosch 191, 2804 (Lot); 8. savoca-coins, ix.2015; 9. silenoccoins, iv.2006

F9. Perinthus, Nero; $\mathrm{RPC}^{\mathrm{S1}} 1761 \mathrm{~A}$ [cmk: ГAАBA]; as, Altar

1. Brock coll., 46; 2. SoS coll., 08; 3. oldromancoins, iii.2003

F10. Perinthus. Nero; RPC 1762 [cmk: ---]; as, Eagle

1. DiB coll., 10 (from Oescus?); 2. DiB coll., 32 (from Oescus?); 3. NiL coll., 08; 4. SaM coll., 586 (= Calomino 2016, fig. 28); 5. Forvm Ancient Coins, rs77050

F11 Perinthus, Nero (head r.); RPC ${ }^{\mathrm{s2}} 1762 \mathrm{~A}$ var. [cmk: Capricon]; as, Genius

1. BuN coll., 02; 2. RaL coll., 28; 3. hermescoins, i.2004

Greek legends

F12. Nicaea; Nero; RPC 2060 [cmk: GALBA]; as(?), Securitas (Poppaea)

1. Del Valle coll. (= [mdelvalle], Nerón); 2. CNG 85, 585 (=Calomino 2016, fig. 29)

F13. Nicomedia, Nero; RPC ${ }^{\text {S2 } 2083 A}$ [cmk: ГAA]; sestertius(?), Decursio

1. $C N G 72,1153$

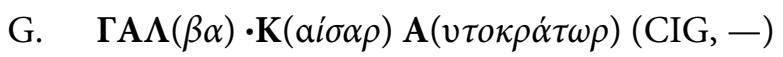

Latin legends

G1. Perinthus, Nero; RPC ${ }^{\mathrm{S} 2}$ 1758A [cmk: standard? FAAY]; sestertius, Decursio

1. SaM coll., 565; 2. CNG E326, 449 (= Pecunem 10, 413)

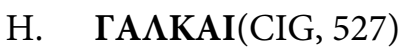

H.1. Lugdunum, Nero; RIC 391; sestertius, Annona

1. Baker coll., 48

Greek legends

H2. Perinthus, Nero; RPC 1748 [cmk: ---]; sestertius, Two cornucopiae

1. CiP coll., 09; 2. SaM coll., 571 (= Calomino 2016, fig. 27)

H3. Perinthus, Nero; RPC 1752 [cmk: ГАМBA]; as, Apollo (cithara)

1. SaM coll., 587; 2. SoS coll., 05; 3. CNG E368, 229; 4. Teutoburger Münzauktion 90, 2239

H4. Perinthus, Nero; RPC 1753 [cmk: ГAגKAI]; as, Apollo

1. Baker coll., 50

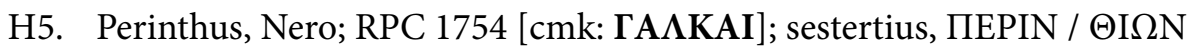

1. LiL coll., 52 (= CNG 93, $751=$ CNG E208, 184); 2. SaM coll., 566; 3. SaM coll., 573; 4. [rennrad12020]; 5. CNG E154, 304 (lot); 6. VAuctions 275, 128 
Latin legends

H6. Perinthus, Nero; RPC 1758 [cmk: ГAגKAI]; sestertius, Triumphal arch

1. Berlin,SM, 26551; 2. Stara Zagora,HM, 5657; 3. BuB coll., 13; 4. DiB coll., 04 (from Oescus?); 5. [illyricum65], vii.2012; 6. LoV coll., 41; 7. MoR coll., 01 (=CNG 78, 1010); 8. CNG E365, 320; 9. Gorny \& Mosch 118, 2089; 10. Gorny \& Mosch 142, 2281; 11. Gorny \& Mosch 176, 2160; 12. Rauch Sommer 2009, 640; 13. Teutoburger Münzauktion 64, 1993 (= Calomino 2016, p.16, fig. 37)

H7. Perinthus, Nero; RPC ${ }^{\mathrm{S} 2}$ 1758A [cmk: standard? FAAY]; sestertius, Decursio

1. MüK coll., 116; 2.SaM coll., 572; 3. SaM coll., 578; 4. SaM coll., 579; 5. artcornucopia 3E, 3386; 6. CNG E124, 243; 7. countryclassic1875, ii.2007; 8. numismatiklanz, vii.2015; 9. Triton XVII.1-2, 619 (A.K. coll.)

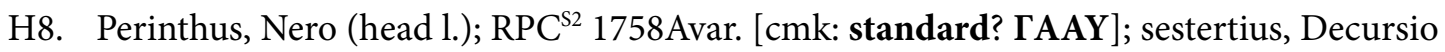

1. Artemideaste E3. 3386

H9. Perinthus, Nero; RPC 1760 [cmk: ГА $\mathbf{B B A}$ ]; as, Neptune

1. Budapest, MNM; 2. SaM coll., 582; 3. SaM coll., 585; 4. WoA coll., 04 (=paganecoins, iii.2004)

H10. Perinthus, Nero; RPC 1761 [cmk: ГA $\mathbf{\text { BAA] }}$; as, Altar

1. SaM coll., 591; 2. Gorny \& Mosch 108, 1720

H11. Perinthus, Nero; RPC ${ }^{S 1}$ 1761A [cmk: ГA $\mathbf{A B A}$ ]; as, Altar

1. MoR coll., 13 (from Utus ?); 2. engsie, ix.2017

H12. Perinthus, Nero; RPC 1762 [cmk: ---]; as, Eagle

1. sproptimo. xi.2013

H13. Perinthus, Nero; RPC ${ }^{\text {S2 }}$ 1762A [cmk: Capricorn]; as, Genius

1. Rauch E19, 216

H14. Perinthus(?), Nero; RPC --- (RIC cf. type 368); as, Victoria(?)

1. [...] (= Mucelli, Contromarche, p. 77)

Modern forgeries

1. GALBA

1A. Roma, Tiberius; RIC 57, 63, 69; sestertius, Shield

1. Gorny \& Mosch 126, 3018 (obv., NERCPP + Head r. ?) (Martini 2005, fig. 8)

1B. Roma, Claudius; RIC 98, 114; sestertius, Triumphal arch

1. nemesis3855, iv.2008 (obv., NERCPP)

1C. Roma, Claudius; RIC 99, 115; sestertius, Spes

1. Rauch 80, 102 [NERCPP + GALBA [x2] + Antonia bust l.(?) (cf. B8.5)]

1D. Roma, Agrippina Senior; RIC 102 (Claudius); sestertius, SC

1. hermescoins, x.2003 (rev. NCAPR) (Martini 2005, fig. 7) 
1E. Roma, Claudius; RIC ---; sestertius, ---

1. ancient_treasures, vi.2011 [x2]

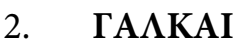

2A. Perinthus, Nero; RPC 1753; as, Apollo

1. Baker coll., 49

2B. Perinthus, Nero; RPC ${ }^{S 1} 1761 \mathrm{~A}$; as, Altar

1. Baker coll., 47

Misreading

3. GALBIMP(---)

3A. (???), Nero(?); RIC / RPC ---; as(?), (???)

1. Sofia, $\mathrm{AM}($ ?) (from Apiaria)

Remarks:

B3.1: worn and deep cleaned coin, local? coinage, poorly definite photograph, damaged G[...]A (modern forgery?), NERCPP subtype?, uncertain identification, need confirmation; B6.3: both GALBA cmks erased; B7.2: uncertain (modern forgery?); B8.2: uncertain (modern forgery?); B8.5: both GALBA cmks erased, with third GALBA modern forgery (cf. 1C.1); B10.10: uncertain (modern forgery?), with ancient $G A L B A($ ?) erased. The erased type on the specimen is recognizable, albeit with some vagueness. At top, in the central part of the punch, the points of the letters $\mathbf{A}$ and $\mathbf{L}$ of the name GALBA seem discernible. Moreover, the size of the incused rectangle appears at odds with the usual shape for NERCPP countermarks, being shorter and taller.(cf. infra, discussion); B13.1: uncertain; B14.1-3: without(?) reverse legend; B14.2: uncertain (modern forgery?): see discussion infra $\$ 3$.J Modern forgery; B14.3: countermark strucked on neck, damaged, GAL[...]; B15.1: uncertain (modern forgery?); B15.2: uncertain (modern forgery?), low definition photograph; strucked on l., behind the head; B18.1: damaged, [...]ALB[...], strucked on neck; C2.2: uncertain identification: need confirmation; C4.2: uncertain identification, damaged, GAL[...]: need confirmation; on Rev. other countermark?; E1.2: in RPC, ГA $\Lambda$, without standard?; E3. wrongly described as standard? ГAAY (see discussion infra $₫$ 3.E; F1.3: uncertain Rev. type (Apollo?); F1.10; only Obv. illustrated, Rev. described like «frontal Apollo»; F1.11: low definition photograph; F2.1: Rev. description cited by seller as «Apollo»; F3.1: damaged, [...] $\mathbf{\Lambda B A}$; F7.3: uncertain; F8.2: damaged, [...]A $\Lambda[. .$.$] ; F8.3: uncertain identifica-$ tion: altar(?) on Rev.; F9.3: only Obv. illustrated, Rev. described by seller like «Divus Augustus altar»; F10.2: uncertain identification: eagle(?) on Rev.; H3.1: damaged, [...]A $\mathbf{\Lambda K A I ; ~ H 5 . 4 : ~ d a m a g e d , ~}$

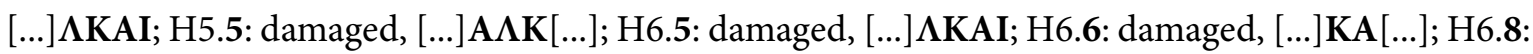
damaged, [...] $]$ KAI, strucked on r., in front of portrait; H7.2: damaged, [...]AI[...]; H7.5: uncertain, low conservation; H7.8: damaged, ГА $\mathbf{\Lambda K}[. .$.$] ; H9.1: damaged, ГА \mathbf{\Lambda}[. .$.$] ; H9.2: damaged, [...] \mathbf{\Lambda} \mathbf{K A I}$; H14.1: the Perinthus new coin type needs confirmation, Rev. described like «Vittoria e scudo con inscritto SPQR (?)» (cf. Plate 4); 1A.1: in identifying the second lexical countermark as NCAPR, head facing right subtype, I had erred. The punch size, especially its height, and the end of the legend that can be discerned, [...]PP, make it likely that this specimen belongs to the Neronian NERCPP type; 1C.1: two ancient erased GALBA (cf. B8.5); 1E.1; modern forgery, seems like ПAW(CI(?) [x2]; 2B.1: "A fake "GAL KAI" on Nero coin (cast copy)» (see www.romancoins.info/cmk-curiosities) 3A.1: Vla- 
dimirova-Aladžova 1986, 36-38; Draganov 1991, 496; Vladimirova-Aladžova 1999, 49, no. 7: «Obverse: Roman inscription: NERO KLAV...AR [...]. Reverse: Damaged, AE, $22 \mathrm{~mm}$ )». The photograph is poorly defined. The specimen's small size, 22 millimeters, makes it nearly impossible to concur with the scholar's identification of the countermark. In all likelihood, this specimen belongs to a group of degraded local manufacture, which typically reproduce the types of the Augustan Tresviral dupondius, countermarked with the AVG and the TICÆ types (cf. Martini 2002, nos. 573-660) or with the TI.C.A type alone (cf. Martini 2002, nos. 3879-3896). These, in turn, are found in degraded writing or incoherent lettering, often poorly struck on the coins or partially illegible. This particular sort of countermark, with its challenging readability, has, over time and not just in this case, fostered the 'creation' of several nonexistent typologies engendered by erroneous or incomplete interpretation.

\section{Countermarks}

\section{A GA(lba) $\mathbf{C}($ aesar $) \mathbf{P}($ ater $) \mathbf{P}($ atriae $)(\mathrm{A} 1,1$ sp.) [Plate 1]}

This countermark, heretofore unpublished and known from a sole specimen in the Brock Collection (A1.1), was struck in an obliterating position inside the punch for the second GALBA found on the obverse of the Claudian sesterce. This corresponds to the placement of the frequently recorded $\operatorname{NER}(o) \mathbf{C}$ (aesar) $\mathbf{P}$ (ater) $\mathbf{P}(\text { atriae })^{3}$, which was often restruck precisely with the GALBA type. This countermark, compared to the more widespread GALBA, appears to constitute an updating of the prosopography for the nomen imperialis by adding the title Pater Patriae, almost as though it wished to recycle the legend from the Neronian type. We cannot establish when this honor was bestowed on Emperor Nero, but the succession of coin legends, especially the epigraphic sequence used for series from the Rome mint, seems to show that use of the PP initialism can be placed toward the end of Nero's reign, starting at the end(?) of the fall of $68 \mathrm{AD} .^{4}$

The GACPP countermark is not without doubt over authenticity, though investigation can be carried out only on a photograph of the sole known specimen so far known. First of all, the abbreviation to two letters of the name Galba begs explanation, since it is usually made up of the first three, GAL or ГA $\Lambda$. Second, the graphic shape of the two letters $\mathbf{P}$, open with the eye drooping toward the base of the legend, though it may be only the impression of the countermark on the planchet, evident precisely in the two final letters, that was distorted by the underlying presence of the GALBA, leaves the outline of the new type indistinct.

\section{B GALBA (B1-B18, 52 sp.) [Plate 1]}

This type is found on imperial sesterces produced in the West (B1-B10) that do not belong to Latinlegend coinage from the Perinthus mint and on seven bronze issues from the Nicaea mint. Of the latter, one is similar to the sesterce in morphology and weight standard (B11). Three correspond to the dupondius (B12-B14) and three to the as (B15-B17). In the case of imperial sesterces, it must be noted that the type is commonly accompanied by the NERCPP countermark, which is often obliterated, placed as a subtype, or by other types, notably including the Nero (radiated head facing right) and the Antonia (bust facing left), both of which are so far unpublished. Several countermark specimens in the first group, found on Western-made imperial sesterces, leave a scholar uncertain

\footnotetext{
${ }^{3}$ Martini 2002, 202, no. 4012, in error, NERCIMP.

${ }^{4}$ Cf. RIC, 243-244; according to Fabbricotti in the beginning of January, after the adoption of Lucius Calpurnius Piso Licinianus (Tacitus, Historiae, I.9) (Fabbricotti 1976, 36).
} 
about whether they are genuine. There can be no doubt about ruling out as modern forgeries the types that feature obvious rounding of the punch edges, belying the fact they were made by pressing rather than striking. ${ }^{5}$ In other cases, we are forced to withhold judgement because the impression left by countermarking is flawed, often only partly legible or with indistinct edges or with lettering that had blended into the underlying coin type (i.e. Plate 3, B8.2).

No die identification has been possible among the recorded specimens, which show morphological differences between the set of countermarks found on imperial sesterces and those on issue from the Nicaea mint. These latter countermarks tend to have been applied with punches whose edges were square, not rounded, to be smaller than the type found on imperial sesterces, and to fit with the various coin morphologies, being larger for sesterces and smaller for dupondii and asses (cf. Plate 4, B16.1). In only one recorded case was the letter $\mathbf{A}$ found engraved without its horizontal bar, thus shaped like $\Lambda$ (i.e. Plate 3, B14.2), giving the specimen yet one more feature to group it among the modern forgeries (cf. infra).

\section{C $\mathbf{G A L}($ ba $) \mathbf{C}($ aesar $) \mathbf{A}($ vgvstvs) (C1-C5, 8 sp.) [Plate 1]}

Documentation of two specimens (C3.1-2) that appeared on the online United States market ${ }^{6}$ had previously enabled me to publish this countermark as spelled GALCAI, hinting that its expansion might give us $\mathbf{G A L}(b a)$ CAI (sar $)^{7}$ if Caesar had been abbreviated in the 'Greek' fashion known to us from Augustan bronze issue from the mints in Ephesus and Pergamum. ${ }^{8}$ The greater number of available specimens and improved quality of their reproductions now allow for correction of the type's identification to propose it be read as GALCA, without the final I (cf. Plate 1, C2.1). The inclusion of the two final letters $\mathbf{C A}$ as an acronym for the $\mathbf{C}$ (aesar) $\mathbf{A}$ (ugustus) initials rather than a truncated CA(esar) would seem preferable to interpreting them as a two-letter abbreviation that is rare in epigraphic contexts.

This countermark, currently known on only a few specimens, is distinguished by the large size of its letters, whose graphics are unrefined. This is especially obvious for the A drawn with a poorly aligned vertical bar and the horizontal bar sloped in 'Greek' style, nearly parallel to the second oblique segment. Our record for this countermark consists mostly of coins from Latin-legend series minted in (C2-C4), two sesterces and an as, along with a sesterce from Rome mint (C1.1) and a sesterce(?) from Nicaea with Greek legend (C5). The latter countermark differs appreciably from the others. Its lettering is smaller and carved in the center of the punch, with nearly hairline ductus that is quite similar to the usual epigraphic standard for the GALBA and ГA $\mathbf{A B A}$ types. It includes two interpuncts before and after the $\mathbf{C}$, spelling out GAL·C.A (cf. Plate 5, Enlargement C5.1), thus confirming, definitively once the lettering can be documented with specimens of better quality and preservation, the above interpretation of the countermark.

\section{D Palladium $\Gamma \mathbf{A}(\lambda \beta \alpha) \mathbf{A Y}(\tau o \kappa \rho \alpha ́ \tau \omega \rho)(\mathrm{D} 1-\mathrm{D} 2,1$ sp.) [Plate 1]}

This countermark has been found only on provincial bronze issue from the Nicomedia mint, the sole denomination being the as(?). It is large and, prior to the two-letter abbreviation $\Gamma \mathbf{A}(\lambda \beta \alpha)$, depicts an

\footnotetext{
${ }^{5}$ Martini 2003a, 112-114, see TI·C $\cdot$ A type «5.3. Falsificazioni moderne».

${ }^{6}$ Martini 2003a, no. 1425 (paganecoins, x.2001); no. 1426 (paganecoins, v.2002).

${ }^{7}$ Martini 2003a, 108-109.

${ }^{8}$ RIC, no. 485 (Ephesus?); nos. 496-500 (Pergamum).
} 
object that Howgego interprets as a standard, a theory provisionally accepted in RPC. ${ }^{9}$ The shape of a "globe atop a triangular feature" ill suits the shape of a legionary standard, which ought to have kept its rectangular shape. Nor does it fit the shape of a trophy, which even in extreme stylization ought to have shown, as its main distinguishing feature, the vertical cross that bore on its sides the spoils of war. The stylized object on the countermarks appears to be made up (a) of a shield, i.e. the broad midsection, (b) a triangular portion, the lower part of the figure, and (c) a sort of small globe, placed at the apex over the top of the shield. It would seem plausible to recognize this image as a depiction of a Palladium, conjured by the essential shapes that make it up: Minerva's head $(=c)$, the shield the goddess holds $(=\mathrm{a})$, and the dress coving the lover part of the divinity's body $(=\mathrm{b})$.

\section{E Palladium $\Gamma \mathbf{A} \Lambda(\beta \alpha)($ E1-E3, 1 sp.) [Plate 1]}

Found applied to a semis(?) and two sesterces(?), both depicting the Decursio scene, one with a Latin legend from the Perinthus mint, the other from Nicomedia, with a Greek legend, this countermark is not recorded in GIC, whereas in RPC there is no mention of the Palladium at the beginning of the legend. The typological identity of the two coins issued at greater value (sesterces) and the unusual countermark type that includes the Palladium, might point to attributing the Latin-legend sesterces with the the Decursio scene not to the Perinthus mint but to the mint in Nicomedia (cf. infra, $₫ 5$. Production). The countermark on the semis(?) from Nicomedia, E3, was described by Howgego (type C) and in RPC (No. 2085) as "standard? ГAAY" and "standard? ГA[AY]," respectively. However, it clearly (cf. Plate 5, enlargements A-B) consists of the type with a three-letter abbreviation for the name Galba. In this sense, it is hard to explain the use of a countermark of such size, even larger than the preceding one (3.D), among other things found only on this one specimen of semis(?), for such a small denomination, a phenomenon we may wish to ascribe, at least until there is greater documentation, to an 'error' on the part of the ancient moneyers.

\section{F ГА $\mathbf{\text { BAA }}(\mathrm{F} 1-\mathrm{F} 13,50$ sp.) [Plates 1-2]}

Found on all the bronze issues countermarked with the "Galba" name except the imperial series from Rome, this countermark seems more prevalent on specimens of less purchasing power, asses and dupondii, than on the higher denomination, the sesterce. The documentation collected has swollen the list of coin series affected to include some not known heretofore. There are three from the Perinthus mint, F4 (sestertius), F6 (dupondius) and F10-F11 (asses), one from the Nicaea mint, F12 (as?), and one from Nicomedia, F13 (sestertius?). The material available reflects a large number of dies, although the countermark is nevertheless distinctive because of its small lettering, properly engraved in mirrored epigraphy on the punch, with almost no signs of slanted writing or copied lettering (cf. Plate 4, F10.3).

\section{G $\quad \boldsymbol{\Gamma A \Lambda}(\beta \alpha) \cdot \mathbf{K}(\alpha i \sigma \alpha \rho) \mathbf{A}(v \tau \sigma \kappa \rho \alpha ́ \tau \tau \rho)(\mathrm{G} 1,2$ sp. $)$ [Plate 2]}

This countermark, found only on two Latin-legend sesterces from the Perinthus mint with the Decursio scene on the reverse, not previously known, might be deemed a mirror-image typology to the Greek-legend type C (cf. supra, 3.C) but could also prove to be the result of an erroneous reading of the latter part of the die, especially in the case of the coin from the antique market, G1.2, while the lettering on the specimen held in private collection, G1.1, appears to leave no doubt. The enlargements (cf. Plate 5, enlargements G1.1-G1.2) show the former coin (G1.1) has clear closure of the

\footnotetext{
${ }^{9}$ GIC, 206, «The object before the inscription may be a standard».
} 
punch edge following the final letter $\mathbf{A}$, with no space for the $\mathbf{I}$ in the abbreviation KAI, while the latter (G1.2) has less careful lettering than the former, although the punch ends on the occipital part of Nero's portrait, blending into the hair and the leaves on the laurel wreath. It nevertheless clearly has no room on the upper left, where the margin dips into the letter $\mathbf{A}$, to fit in another letter. This type may be considered along the lines of a variant of the following one, in part because of the current limited number of specimens covered in documentation. Thus, our proposal for the last two letters is the same completion proposed for type C, i.e. a two-letter acronym $\mathbf{C A}$ for $\mathbf{C}$ (aesar) $\mathbf{A}(v g v s t v s)$, later taken on as an initialism for $\mathbf{K}(\alpha i \sigma \alpha \rho) \mathbf{A}(v \tau o \kappa \rho \alpha \dot{\tau} \omega \rho)$. The existence of an interpunct following the three letters $\mathbf{\Gamma A \Lambda}$ is certain (cf. G1.1), whereas we cannot establish whether there is any diacritic between the two following letters. Only specimens of higher quality and better preservation will allow for clarification of the lettering, be it KA or $\mathbf{K} \cdot \mathbf{A}$, although a two-letter abbreviation KA for $\mathbf{K A}(i \sigma \alpha \rho)$ would seem unlikely.

\section{H $\boldsymbol{\Gamma A \Lambda}(\beta \alpha) \cdot \mathbf{K A I}(\sigma \alpha \rho)(\mathrm{H} 1-\mathrm{H} 13,48 \mathrm{sp}$.$) [Plate 2]$}

Second most widespread, surpassed only by the ГА $\mathbf{\Lambda} \mathbf{B A}$ type, this countermark has been found almost exclusively on bronze issue from the Perinthus mint, with particular prevalence on series with Latin legends, preferably the higher-denomination sesterce, rather than the as, with no dupondii yet known to bear this type. The sesterce specimen from the Lugdunum mint that has the Annona scene on the reverse, held in a private collection (cf. H1.1), must be deemed an exception to the norm of countermark application, though nevertheless bringing new testimony to the penetration, albeit in limited number, of imperial-issue sesterces into circulation around Moesia and Thrace, whereas this denomination is rather well attested in Pannonia. The countermark is fairly standardized in its lettering, reflecting a small number of dies, and there have been no record of any particularly degenerate lettering (cf. H3.1) or copied writing. This typology can likely be divided into two main groups (cf. infra, Circulation). The first (a), less common, is distinguished by its smaller punch size and smaller lettering compared to the second (b), which is broader with letters whose ductus is thick and pronounced (Plate 2). The two groupings have different anomalies, noted here as "uncertain size" (cf. Plate 2), and there seems to be no precise rule for application, in that both the first "large size" type (cf. Plate 2) and the second, "small size" (cf. Plate 2), recur on Perinthus issue regardless of whether the legend is in Greek or Latin and regardless of whether the coins are sesterces or asses.

\section{I Uncertain [Plate 3]}

The first six specimens in the catalog, which belong to the GALBA type, B8.2 and B10.10 (sesterces from Rome, Claudius), B13.1 and B14.2 (dupondii? from Nicaea, Nero), and B15.4 (asses? from Nicaea, Nero) and to the ГA $\mathbf{\Lambda} \cdot \mathbf{K A I}$ type, H7.8 (sesterce from Perinthus, Nero), seem more likely to be modern forgeries than poor-quality engravings. The B8.1 specimen looks closely tied to B14.2, possibly its inspiration. The B10.10 countermark is distinguished by its small punch and diminuti ve lettering, with the initial $\mathbf{G}$ shaped like a C. In B13.1 we not only come upon a rerun of the 'open' kind of $\mathbf{C}$ but note how the decadent lettering stands out, especially the letter $\mathbf{L}$, whose horizontal bar is elongated. Specimen B15.4 takes up the orthogonal lettering with thick, squared-off ductus that is typical of many GALBA type countermarks, such as B5.2, for example. The lettering on H7.8 stands out for originality, only partly(?) imprinted as $\mathbf{\Gamma A \Lambda K [ . . . ] , ~ d u e ~ t o ~ a ~ p r o c e d u r a l ~ f l a w ( ? ) ~ o r ~ s o m e ~ i n t e n - ~}$ tion on the part of the moneyer(?), and used smaller letters than usual for the $\mathbf{\Gamma A \Lambda} \cdot \mathbf{K A I}$ countermark that look overall very much like the lettering usually employed for the ГАМBA type.

Things are a bit different for the other two uncertain specimens. One is tentatively assigned in the 
catalog to the ГА $\mathbf{\Lambda B A}$ type, F13.1 (sesterce? from Nicomedia, Nero) and the other to the $\mathbf{\Gamma A \Lambda} \cdot \mathbf{K A I}$ type, H7.6 (sesterce from Perinthus, Nero). The graphics of their lettering cannot be immediately ascribed to any of the presumed original models.

The F13.1 countermark, in all likelihood, if taken to be a ГA $\mathbf{\Lambda B A}$ type, certainly has unusual lettering, starting with its oversize breadth that brings it right to the edge of the four sides of the die. Nor do the letters sit at the center of the epigraphic field defined by the punch. The idiosyncrasy continues with the shape of the presumed letter $\mathbf{B}$, lettered in the shape of a $\Pi$, i.e. as an open $\mathbf{P}$ with its eye extended toward the base line. If the lexical identification of this countermark, along with its authenticity, can indeed be ascertained, it would extend the use of the ГА $\mathbf{\Lambda} \mathbf{B A}$ type to the Nicomedia mint.

The other specimen, H7.6, is not likely to garner quite so much interest, since it fits into a fairly homogeneous set of coins. It appears to consist of an imitation in writing of a $\mathbf{\Gamma A \Lambda} \cdot \mathbf{K A I}$ type, whose lettering works out to $[\Gamma] \mathbf{A \Lambda H} \mathbf{I}$. There is less likelihood in this case that it might actually be a sloppy modern forgery, although the examination on its photographic reproduction cannot be considered conclusive reasoning.

\section{J Modern Forgeries (1A-1E, 2A-2B, 7 sp.) [Plate 3]}

The problem of identifying modern forgeries primarily involves sesterces from the Rome mint with the GALBA countermark and Perinthus sesterces, with either Latin or Greek legends, countermarked with the $\mathbf{\Gamma A \Lambda} \cdot \mathbf{K A I}$ type. Only to a lesser extent does it affect other types and smaller denominations, which are obviously less attractive targets for 'reproduction' because they hold less trading interest and market value. Recorded here under "Modern Forgeries" are a few almost certain examples of countermarks of modern manufacture (cf. 1A-1E, 2A-2B) A few specimens are also illustrated in the plates under the rubric of "Uncertain" (cf. Plate 3) and included organically in the catalog but with brief discussion of whether they are to be deemed modern forgeries or decadent writing and lettering that imitate known countermarks (cfr. supra, $₫$ 3.I. Uncertain). Investigation into these coins is complicated, as mentioned above, both by the limited amount of material documentation currently completed and by the private nature or antique-market provenance of availabe specimens, factors that allow for neither proper typological comparison nor direct inspection, thus leaving the investigation to rely perforce on photographic reproductions, which are often poor qua lity.

The examples of possible modern forgeries show up in various ways. The countermark on speci men 1A.1 was most likely achieved by pressing rather than striking (cf. note 5), and appears along side two ancient types, on the reverse, head facing right, which overstrikes the NERCPP mark (cf. supra, 2. Material, $\S$ Remarks). Specimens 1B.1 and 1D.1 are ancient coins on which someone in re cent times has added the GALBA type. In both cases the countermark is accompanied by an au thentic countermark, NERCPP (1B.1) and NCAPR (1D.1), respectively. ${ }^{10}$ The case of specimen 1C.1 is a bit more complex. The coin is countermarked with a probably modern-made GALBA type in the center of Claudius's portrait pressed into the surface (?) and has two more GALBAs on the sides overstruck on Antonia (bust, left) and NERCPP (right), both authentic and efaced, likely ancient. Two other Perinthus specimens, 2A.1 and 2B.1, both countermarked ГA $\Lambda$ KAI, have been deemed counterfeit, both as coins and as countermarks. The former seems to have been struck(?) in modern times, probably with a die carved by copying an original specimen. The latter is a cast repli ca of a countermarked ancient

\footnotetext{
${ }^{10}$ Martini 2005, 24, fig. 7.
} 
coin.

The nature of the material and the limited known documentation, almost exclusively from sales catalogs or private collections with the concomitant challenges to analysis inherent in working only from photographic reproductions, mandates extreme caution in judging the authenticity of specific coins. Be that as it may, in spite of the meager number of specimens, an outline of rather uniform behavior for groups of countermarks can begin to be drawn, highlighting any possible outliers. For example, the Nicaea sesterce (B14.2) recorded here in the catalog despite its dubious originality stands apart from the other coins because it is the only case of the GALBA countermark showing up in lettering just like what is found on the imperial sesterces (B1-B10). This is in sharp contrast to what occurs for the other specimens from this mint (cf. B14.1 and B14.3) (cf. supra). Should gro wing documentation confirm the anomaly of this specimen, it would most certainly have to be classed among modern forgeries.

\section{Function}

Beyond the shadow of a doubt, the primary function of countermarks with the name "Galba" on the issues chosen for countermarking was political. This function was fulfilled both directly and indirectly, whereas there do not seem to have been instances in which the countermark was used primarily for economic purposes as a way to validate bronze specie already in circulation. The provin cial administration chose two different methods for carrying out the damnatio of Nero in favor of Galba. It operated on issues of differing legal status, imperial and provincial. The former, (a), direct, represented Galba's 'political pronunciamento'. The latter, (b), indirect, implemented Nero's dam natio memoriae.

The lower Danube was the region of the Empire where Nero's portrait saw its most widespread, systematic damnatio ${ }^{11}$, defying all comparison with other areas, especially in Gaul, in terms of the numerous countermarks from the periods of the Civil Wars and Vespasian ${ }^{12}$, or in Pannonia where the [legio] XI [Clavdia Pia] type was used. ${ }^{13}$ With these types, there was no systematic erasure of Nero's imperial portrait; rather, the new authority was simply proclaimed in Gaul, while in Panno nia coins were distributed among the Legions with the numeral XI for Legio XI.

\subsection{The Political Pronunciamento}

Indirect intervention took the form of the sole countermark GALBA, added to various coin series:

${ }^{11}$ Calomino 2016, 67 «The numismatic evidence shows that some official actions were taken in some regions [...] to delegitimise Nero's authority [...] The spread of countermarking of his bronze coins as a political measure was unparalleled; the marks were mostly stamped on his portrait, although not necessarily with the intent of defacement».

${ }^{12}$ Cf. cmks: S(enatvs) $\mathbf{P}($ opvlvs $) \mathbf{Q}(v e) \mathbf{R}($ omanvs), Calomino 2016, 68, no. 23, Martini 2003b, nos. 26-27; $\mathbf{P}$ (opvlvs) R(omanvs), Calomino 2016, 68, no. 24; $\mathbf{P}$ (opvlvs) $\mathbf{R}$ (omanvs) [retrograde], Calomino 2016, 68, no. 25; VESPA(sianvs) [ligature], Calomino 2016, 69, no. 31, Martini 2003b, no. 35; VITE(llivs), Calomino 2016, 69, no. 30; Kos - Šemrov 1995, 62, remark «[...] countermarks on the neck of Nero's bust can also be interpreted as a damnatio memoriae of a despised and slain emperor, in addition to the basic function of legionary countermarks»; see also Savio 2009, passim.

${ }^{13}$ Cmk [Legio] XI: Mac Dowall 1960, 103-106 (like X); Calomino 2016, 69, no. 26, Martini 2003b, no. 82; Kos - Šemrov 1995, 59-62. 
(a) imperial sesterces from the Rome mint, coined between the reign of Tiberius and the reign of Claudius (B1-B10); and (b) provincial issue with the Greek legend from Nicaea (B11-B17). ${ }^{14}$

(a): On the first group of specimens (B1-B10), there was no need to obliterate the portrait as was done on other series because it was not Nero's. It was enough to proclaim Galba the new imperial authority. One case has been documented of a different portrait being obliterated, a portrait of Ne ro Drusus (cf. B5.1), which is to be understood as an obvious minter's mistake. Evidence shows there was an outright, indirect damnatio of Nero's NERCPP countermark through its systematic obliteration on numerous imperial specimens via two different means: (a1) simple mechanical era sure of the legend (cf. Plate 5, B8.3) or (a2) by superimposing the GALBA countermark, often twice on the same coin arranged vertically next to the portrait, with one countermark struck inside the mold of the earlier Neronian type, thus nearly wholly obliterating it and almost always leaving Galba's new type essentially illegible as it blended into the preceding countermark (cf. Plate 5, B5.3). This may help explain why ancient minters felt the need to countermark the same coin twice with the GALBA type, only one of which came out identifiable.

(b): The second group is made up almost entirely of Greek-legend issue from the Nicaea mint in va rious denominations. Comparison with weight standards from the Rome mint is not always straightforward, however, though these appear to be the sestertius(?), the dupondius(?), and the as(?). Here, the graphics of the GALBA countermark differ from those of the previous group, its overall size being smaller to suit the different morphology of the issues on which it was placed (cf. supra) and the rounded punch have been given up in favor of the square kind. In that regard, doubt may be cast on the authenticity of certain known specimens of the GALBA found on imperial sesterces whose punch clearly had rounded edges, a feature not found on the coins from the Nicaea mint. The different punch shape is only one of the features that call into question the authenticity of specimens such as B14.2, whose cataloguing is under doubt (cf. supra, $\$ 2$. Materials).

\subsection{Damnatio Memoriae [Plate 4]}

Direct political intervention: (a) employed all the countermarks with the "Galba" name, (b) invol ved only denominations with Nero's portrait, except for the Nero Drusus sesterce (B5.1) (Plate 4), whether issued by provincial mints in Perinthus, Nicaea, and Nicomedia or coined at an imperial facility, though as yet we have only a single such specimen, a sesterce from the Lugdunum mint in a private collection (H1.1) (Plate 4) with the $\mathbf{\Gamma A \Lambda} \cdot \mathbf{K A I}$ type, and (c) clearly aimed to systematically 'erase' the image of the execrated emperor and proclaim the new Romna authority. This brings the specie circulating in the lower Danube into the purview of the overall damnatio memoriae, a syste matic operation carried out with special vehemence on coinage that affected Nero in both Western and Eastern regions of the Empire. ${ }^{15}$

The materials collected show the overall behavior of countermarks, all struck on the obverse of the specimens for the primary purpose of obliterating the imperial portrait, though results of the opera-

\footnotetext{
${ }^{14}$ Mac Dowall 1960, 107-108, “Copper As", "Sestertius" or "Dupondius"; Howgego 1985, 90 «[...] three of what (Nicean coins) which are presumably dupondii»; Kaenel 1984, 141 «Sesterzgrösse» and 142 «Dupondiusgrösse»; RPC, 318 «[...] Perinthus was almost certainly the mint of some 'Roman' type sester tii, dupondii and asses of Nero».

${ }^{15}$ Varner 2004, $\S$ Nero and Poppaea, 46-86 (use of countermark ГА $\Lambda$ BA, 51); Howgego 1982-83, passim ( $\$$ 3. Occasions, 50-52); Calomino 2016, passim.
} 
tion vary. The damnatio is, in some cases, carried out perfectly (cf. Plate 4, B14.1, F1.6, H1.1, H5.4, H6.12, H10.3). On other coins Nero's portrait has been only partly removed (cf. Plate 4, C4.1, F10.3, F12.2, H5.1). Finally, there are coins on which the imperial profile is nearly intact (cf. Plate 4, B16.1, H9.1). The determination to condemn the image, which called for striking the countermarks on a portion of the coin surface ill suited to the new strike, made it hard to achieve a proper impres sion for the various "Galba" types, which often end up illegible (cf. Plate 4, F1.7). The countermarks often blend with the features of Nero's portrait that are in highest relief, such as the neckline, the chin contour, the nose profile or the bangs. Adding to the challenge of the peculiar placement on the planchet surface are detriments to proper countermark application that arise due to the use of rather large punches. This is especially apparent with the epigraphic 'length' of the ГA $\mathbf{\Lambda B A}$ and $\Gamma \mathbf{A} \mathbf{\Lambda K A I}$ types.

\section{Production}

The coins subject to countermarking fall into two distinct categories, (a) those with Greek legends coined in Perinthus, Nicaea, and Nicomedia, whose ethnicity obviously traces to the mint of origin, although there used to be some uncertainty over a few specimens with no mint mark that have now been brought back into the series from the city ${ }^{16}$, and (b) those with Latin legends, whether coined in the Rome mint, the sole such denomination being the sesterce, or provincially issued sesterces, dupondii, and asses, which are currently attributed across the board to the Perinthus mint. ${ }^{17}$

Current knowledge does not allow for precise identification of the location of manufacture of the coins with Latin legends and Roman types to which countermarks in the "Galba" name have been applied, although we can be fairly certain their origin falls into the general area of Moesia and Thrace. When analyzing the ГA $\mathbf{\Lambda} \mathbf{B A}$ type alone, MacDowall had theorized, partly because of what is known about circulation in the period, that the coins came from a mint in Moesia ${ }^{18}$, whereas in RPC, the series with Latin legends are attributed only to the Perinthus mint, on the basis of the fact that the same countermarks used on Greek-legend specimens with city symbols are found on Latin-legend issue. However, this is not a determining factor because countermarks with identical typolo gy are found without distinction on bronze coinage from Nicaea and Nicomedia. This deprives the wish to equate the same countermark with the identical mint of any basis in fact.

The broad range of morphology both for Nero's bronze issue and for countermarks in the "Galba" name rightly leads us to theorize the existence of several manufacturing locations that operated at the same time. For the coins, we know of a large number of dies, of differing quality, with various imagery. Among the countermarks, we find variety in both size and writing. The separate produc tion centers were likely tied to urban areas as well as the main settlements and encampments of le gionaries

\footnotetext{
${ }^{16}$ RPC, 349, Nicomedia «Other Bithynian coins without ethnic [...] should perhaps be attributed to Nicomedia [...] One of the coins discussed [...] has been attribuited to Nicomedia (2084) [here, D1], since it has the same countermark as occurs on two definitely Nicomedian coins».

${ }^{17}$ RPC, 318, «These rare coins [...] have the same Galban countermarks as coins of Perinthus [...] the same punch was used to apply the countermark on both sort of coins [...]. In view of the fact that countermarks were generally applied by a mint on to its own coins, the attribution of the Neronian coins to Perinthus seems reasonably sure».
}

${ }^{18}$ Mac Dowall 1960, 106 «[...] seems to have been applied locally at a centre in Lower Moesia». 
throughout the lower Danube region (cf. infra, $\$ 6$. Circulation).

By encouraging on a broad scale in the lower Danube region the striking of coins with Latin le gends, with the portraiture and weight standards of the Rome mint, the imperial administration followed and carried to its extreme a practice that had lasted for the whole history of coinage in the Empire. This practice consisted of making bronze coin under the direct authority of the military administration, presumably centered in the main legionary encampments along the limes. ${ }^{19}$ Viewed in this light, the hypothetical attribution of Nero's Danube issue with Latin legends solely to the Perinthus mint loses substance, especially since it leaves unexplained the (a) morphological and (b) stylistic variations between the Latin-legend and Greek-legend series. The latter, corresponding to sesterces and dupondii, were coined in bronze and orichalcum, whereas the Latin-legend series were only in bronze. ${ }^{20}$ Though hard to establish with current limited documentation, it seems plau sible that Nero's facial features on the Latin-legend Perinthus coinage were reproduced using more cursive iconographic models than had been followed for the Greek coinage. The Greek series ad here more closely to the imperial prototypes of Western mints in Rome and Lugdunum.

It thus seems reasonable to ascribe the output of Neronian coins with Latin legends and counter marks in the "Galba" name to more than one manufacturing location and not only to the Perinthus mint. Improvements in documentation and better understanding of the locations of coin finds, which are currently limited to a meager number of reports or information gleaned from the antique market or the knowledge of individual private collectors, may make it possible to identify different production centers for the coins and application points for the countermarks.

Within the group of countermarks in the "Galba" name, it nevertheless seems plausible to isolate a set of specimens with the GALBA type struck on imperial sesterces (B1-B10), as distinct from the rest of the countermarked coins, whether with the Latin or the Greek legend, including those from the Nicomedia mint with identical typology (B11-B17) (cf. supra $\$ 3$ B). Imperial sesterces often bear the GALBA type along with the Neronian NERCPP type, which has not turned up on any ot her issue from the area, thus setting this set's originality off from the remaining provincial materials and hinting at a different location for the application of countermarks. The spread of the GALBA countermark, as well as the often accompanying NERCPP countermark, across several Hungarian collections (i.e. $\mathrm{BuB}$ coll., DeO coll.), some of which have marked geographic emphasis, and reports of presumed Pannonian origin (i.e. B5.1, B10.9, MüP coll., 39) might point to Pannonia as the area where the countermark that appears on imperial Roman sesterces was produced and circulated. In this regard, we know the sestertius denomination was widely used in the region, as attested by the widespread [legio] XI type (cf. supra) whose application has been traced without contention to Pannonia. ${ }^{21}$ On the other hand, countermarked imperial sesterces appear rare and poorly spread in Moesian and Thracian circulation, save for the few specimens with the goat/rudder ${ }^{22}$ and excluding the DV type,

\footnotetext{
${ }^{19}$ Martini 2017, 235-237; also the countermarked cast coin from Carnuntum, Hahn 1976, 32, no. 202 «Münz Km. (mitgegossen)»; Martini 2003b, 20-25 (see also supra, note 2).

${ }^{20}$ RPC, brass: no. 1748 (in error, bronze), no. 1752 and no. 1754; bronze: nos. 1752-1753.

${ }^{21}$ Mac Dowall 1960, 103, «[...] seems to have been applied locally in one of the Upper Danubian pro vinces, almost certainly Pannonia»; Kos - Šemrov 1995, 59, «A countermark [...] which was found some where in the area of Ptuj (Poetovio)» and 61, «Ptuj (Poetovio) [...] the countermarks had belonged to the legio XI Claudiam as exactly at this Pannonian site»; Martini 2003b, no. 82.

${ }^{22}$ Martini 2003a, 110-111, nos. 1444-1446, no. 1448.
} 
which has to belong to a period after the 68-69 AD Civil Wars. ${ }^{23}$

Although further verification is needed, available evidence about the GALBA countermark appears to show that the type, when found on imperial sesterces (B1-B10), not only in the company of the Neronian NERCPP type, is to attribute to the southern part of Pannonia, the area known from the second century AD as Pannonia Inferior.

Another observation can be made about sesterces that bear the Decursio scene on the reverse. Re cent documentation has included not only the two series RPC 2103-2104, previously assigned to an "uncertain mint in Bithynia," but also two other issues, one made in Perinthus, RPC 1758A, with a Latin legend, that has DECVRSIO on the exergue and one from Nicomedia, RPC 2083A, whose exergue bears the ethnic name of the city in Greek, NEIKOME $\triangle \mathrm{E} \Omega \mathrm{N}$. The latter two specimens have enabled us to extend attribution to the Aisa Minor mint to the former two issues (RPC 2103-2104) as well. The Palladium $\Gamma \mathbf{A} \Lambda(\beta \alpha)$ countermark, if we exclude the isolated case of a semis(?) (RPC 2086), has currently been found only on two recently identified coin series, RPC 1758A (Pe rinthus) and 2083A (Nicomedia). This makes it possible, on the one had, to theorize that the type was applied precisely in Nicomedia or, at any rate, in Asia Minor and, on the other, that the series deemed issued in Perinthus with the Neronian Decursio scene, despite their Latin legend, might al so belong to the Nicomedia mint(?).

\subsection{Imperial Coinage and Military (or Localized) Issue}

At the current state of documentation, known specimens of sesterces with Latin legends so far attributed to the Perinthus mint belong to only two typological series, the Triumphal Arch and the Decursio. This allows for an initial observation on the propaganda dynamics of the Nero administra tion, specifically with regard to the legionary context. Western bronze issued during Nero's reign breaks down into the distinct production of the Rome and Lugdunum mints, two sequences of coinage in nearly identical denominations and types, with those of the Gaulish mint recognizable by a small globe at the end of the neckline on Nero's portrait. ${ }^{24}$

The series with Latin legends from the Danube and/or Asia Minor region fit into the pattern of localized manufacture of bronze coin. However, they differ from Lugdunum issue (a) in the lack of the distinctive feature of the small globe for the mint in Gaul, (b) in using only certain typologies from Rome, and (c) in adding 'original' imagery compared to imperial coinage. As far as (a) is con cerned, we have already noted that the primary criterion for distinguishing the Danube and Asia Minor series is still their morphology and, above all, their stylistic judgement. In terms of (b) the typologies are (i) the Triumphal Arch (RPC 175, cf. RIC, 136, type 4) (cf. Plate 5, H6.8), (ii) the De cursio (RPC 1758A,

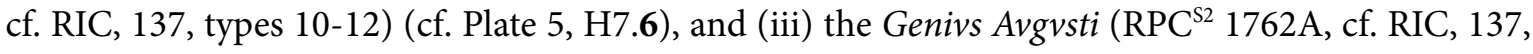
types 13) (Plate 5, RPC ${ }^{\text {S2 }}, 1762 \mathrm{~A}$ ). Types that illustrate (c) include (iv) the Pro vident (RPC 1761), (v) the Eagle (RPC 1762) and (vi) the Neptune (RPC 1760). The first two were used for Tiberius' issues in the name of Divus Augustus (RIC 81-82) and the third for Caligula's se ries commemorating Agrippa (RIC 58). There are obvious relations between all the types cited (i-vi) and the legionary context. Direct reference to Nero's military activity ${ }^{25}$ is made by the Trium phal Arch (i) and the Emperor as

\footnotetext{
${ }^{23}$ Martini 2003b, 151, note 391.

${ }^{24}$ RIC , 142-144, $₫$ Aes of Lugdunum (nos. 371-606).

${ }^{25}$ Smith 2000, 283-284, $\S$ The Praetorian Guard and coinage, «To conservative Romans the statio ning of the Praetorian guard in Rome was one of the most offensive features of the principate».
} 
knight (ii) ${ }^{26}$ The image of Neptune (vi) recalls the god who pro tected the fleet stationed in the lower Danube and the Legio XI Claudia Pia Fidelis. The two Tiberi an depictions (iv-v), referring to the Augustan cult, had immediate evocative power, the Eagle (v) as a legionary symbol par excellence and the Provident (iv) as founder of the Empire and the personifi cation of political-administrative gifts, as well as being the Julian-Claudian bronze issue that may have had the most capillary spread through Western regions, often used for votive or funerary pur poses. Finally, the last type, (iii) the Genius Avgvsti, also seems to trace back to some generic legio nary context as a function of its wish to assimilate Nero to Apollo, a divinity whose persona (iii) may hark to the god who protected the Legio XV Apollinaris, portrayed on two Greek-legend issues from the Perinthus mint, showing Apollo-Nero Citharoedus (RPC 1752, cf. RIC 136, type 3) and Apollo with scepter (RPC 1753).

The bronze series from the mints in Rome and Lugdunum, whose types show obvious relation, thus represent "imperial coinage" we might term 'centralized,' under the direct control of the administrative apparatus in Rome, whereas production from Perinthus or Asia Minor represent "military (or localized) issue" that met different needs from the foregoing. Such coinage was less closely bound to the complex, multifaceted institutional framework of Roman politics and Roman society, more directly aimed at the legionary user. As a result, it chose evocative iconographic themes that tied in neatly with military life, while keeping as its main purpose the supply of small denomina tions for everyday transactions.

The innovation introduced under Nero, in addition to sanctioning the existence of bronze issue outside Rome with the identifying 'mark' of the Lugdunum mint, a graphic expedient that had not been used earlier for series minted in Gaul and Hispania under Caligula and Claudius ${ }^{27}$, can be seen in the different organization of localized legionary coinages. Localized coinage had been known since the time of Augustus ${ }^{28}$, but was now no longer relegated to the role of useful but unthinking 'copies' of prototypes from the Rome mint. It was now a recognized and coherent element in a broader, complex framework of imperial policy. The coin was directly tied to the milieu of the legi ons not only in their primary military function but also in terms of the equally important part they were to play in the social makeup of provincial territories.

\section{Circulation}

Little certain archaeological evidence is available to us. ${ }^{29}$ 'Territorial' characteristics that can be inferred from the antique market and from private collections (cf. supra, Materials) ${ }^{30}$ certainly point to

${ }^{26}$ Contra Smith 2000, 284-285, $\$$ The problem of the DECVRSIO types, «[...] the scenes depicted are not military displays at all, but a form of theatre [...]».

${ }^{27}$ Besombes 2003-2004, 23-26.

${ }^{28}$ Martini 2017, 236-238.

${ }^{29}$ (29) See Vladimirova-Aladžova 1986, 36-38; Vladimirova-Aladžova 1999, 45-49; Draganov 1991, 495 (ГА $\Lambda \cdot$ KAI, da Nova Zagora).

${ }^{30}$ GALBA: B10.5, DeO coll., 15 (from Sopianae area(?); B10.7, DeO coll., 17, from Sopianae area(?); B10.9, MüP coll., 39, from Mursa(?); Bulgarian private coll., from Asamus(?) (Martini 2002, no. 4009); Budapest, MNM, gift 2000, from the Pannonia area (id., no. 4012); ГA ABA: F8.3, MoR coll., 10, from Utus(?); F10.1, DiB coll., 10, from Oescus(?); F10.2, DiB coll., 32, from Oescus(?); Budapest, MNM 54.A.1921.93, from the Pannonian area (Martini 2002, no.4051); ГA $\mathbf{K A I}$ : H6.3, DiB coll. 04, from Oescus(?); H11.1, MoR coll., 13, from Utus(?); Stara Zagora, HM 4 sz 5657, from Stara Zagora(?) (Martini 2002, no. 4055); two Bulgarian private 
production and circulation in Moesia and Thrace for a substantial portion of the countermarked coins, with two exceptions. The first is for imperial sesterces with the GALBA type, whose spread (and striking?) can most likely be attributed to areas farther to the west, probably including Panno nia (cfr. supra). The other exception concerns certain series from Bithynia in Asia Minor, which can be attributed to mints in (or around?) Nicaea and Nicomedia.

The theory that most of the countermarks with the "Galba" name circulated around the lower Da nube allows for the identification of specific distribution dynamics for bronze coin. Evidence shows that provincial issue from the Nicaea mint with the GALBA, GALCA, and ГA $\mathbf{B} \mathbf{B A}$ countermarks and from the Nicomedia mint with the latter Greek legend, of which there is fair attestation in the area, were assimilated to series minted in Perinthus, with legends in both Latin and Greek. These coins circulated together and together were countermarked with certain imperial Galba types.

The clear distinction within the GALBA group in denomination and die morphology between imperial specimens (B1-B10), leaving out some possible modern forgeries (i.e. B8.2, B14.2), and the provincial specimens (B11-B17), which all belong to issues from the Nicaea mint, seems to suggest that we can identify two distinct contexts for countermarking, as well as circulation. The former coins can be placed around Pannonia. The latter can be traced to an area other than the lower Da nube, quite possibly Nicaea itself or another part of Asia Minor to be identified somewhere in Bi thynia. This last hypothesis might find favor in the exclusive use of issue from the city for counter marks with the Latin GALBA type, a fact that, otherwise, given what is currently known, would appear to have no reasonable explanation.

As documentation continues to be collected, additional distinctions within the group of countermarked sesterces may be confirmed. These are currently to be considered only as possible working hypotheses to be tested: (a) It may be possible to separate the specimens with the GALBA type alone, often twice, from coins where it is accompanied by NERCPP, which it often obliterates; and (b) there may ultimately prove to be a different geographic determination for specimens whose GALBA countermark has been erased or damaged.

For (a), information on the circulation of imperial sesterces around Pannonia always refers to the two types GALBA and NERCPP together (i.e. B2.1, B5.1, B5.6), suggesting that both belong to that region. For (b), erasures of the GALBA countermark have so far been found only on four speci mens of sesterces ${ }^{31}$ (cf. Plate 4, B8.5, B10.10), which demonstrates the existence of the phenome non, almost certainly during the period after the emperor was sentenced to damnatio memoriae but before he was rehabilitated under Vespasian. ${ }^{32}$ Furthermore no accompanying NERCPP is to be found, which might -- with all the caution warranted by our limited documentation -- theoretically hint at a different geographic destination compared to the preceding specimens, if not an outright different venue of manufacture. At the very least, we might shift their circulation somewhat east ward from Pannonia,

coll., from Utus-Augustae (id., nos. 4056, 4058).

${ }^{31}$ GALBA [x2], both erased: (1), Martini 2002, no. 4009; (2), Martini 2003a, no. 1424; (3) B8.5, Rauch 80, 102; GALBA(?), B10.10: the countermark erased is recognizable with fair, albeit not total, certainly. The points of the letters $\mathbf{A}$ and $\mathbf{L}$ in the GALBA name appear discernible at the top, in the center portion of the punch. Furthermore, the size of the incused rectangle does not look compatible with the usual shape of NERCPP countermarks, compared to which it is narrower and taller.

${ }^{32}$ Bianchi 2014, 45-46; Varner 2004, 106. 
along the lower Danube estuary into a wholly Moesian context, on the strength of the probable provenance from that area of two of the four specimens. One was likely uncovered around ancient Asamus. ${ }^{33}$ The other belonged to a private Bulgarian collection at the time of its first documentation. ${ }^{34}$

The available material appears to show some practically stabilized 'behavior' on the part of the countermarking operations. Issues from the Nicaea mint are involved almost exclusively in countermarking with the Latin-legend GALBA and GALCA countermarks, except for three specimens with the ГA $\Lambda$ BA type (F12.1-2, F13.1). Similarly, on series from the Nicomedia mint we find only types with

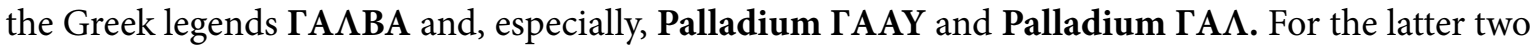
types, these represent the only coins with such countermarks, save for one specimen from Perinthus (E1.1), though the attribution of a venue to the coinage of this issue, which bears on its reverse the Neronian scene of the Decursio, might be shifted to none other than Nicomedia, thus confirming the idea that these two countermarks were struck only on coins from mints in Asia Mi nor (cfr. supra).

Only on asses and sesterces, including a few with the Neronian scene of Decursio on the reverse, from the Perinthus mint, in both Latin and Greek lettering, do we find the ГA $\mathbf{\Lambda} \cdot \mathbf{K A}(\mathrm{G} 1)$ and $\mathbf{\Gamma A \Lambda} \cdot \mathbf{K A I}$ (H1-H13) types, with the sole exception known so far of a Lugdunum sesterce (H1.1). Here, again, available documentation would tend to point to Perinthus as the main location for countermarking the two types, theorizing circulatory drift into Thrace of the not-yet-countermar ked sesterces with the Decursio scene from Nicomedia, should attribution to the series from the Asia Minor mint not be settled upon (cf. supra).

The theory that the sesterces with the Neronian Decursio scene drifted away from the Perinthus mint would, however, seem hard to reconcile with the behavior of the ГA $\Lambda$.KAI type mentioned above (cf. supra, Countermarks 3.H), which shows up in two distinct morphologies. One is smaller, with graphics wholly analogous to the $\mathbf{\Gamma A \Lambda \mathbf { B A }}$ type. The other, distinguished by larger punches and broader letters (cf. supra, and Plate 2, "large size" and "small size"). Given current information, it seems impossible to identify a single same behavior for the two countermarks. The recur with no distinct pattern on all issue from the Perinthus mint, including the sesterces with the Decursio scene, in no apparent order, a fact that calls into question the aforementioned possible manufactu ring distinction that would have the striking of specimens depicting the Neronian type take place only at the Nicomedia mint.

\section{Conclusion}

The growth of documentation collected has made it possible to: (a) increase the number of countermark types from those listed in GIC; (b) update the coin issues and countermark distribution outli ned in RPC; (c) better specify iconography for the two types with the Palladium image; (d) start an initial discussion of modern forgeries for the GALBA type; and (e) improve our geographic delimitation of possible location for the production and circulation of the countermarks.

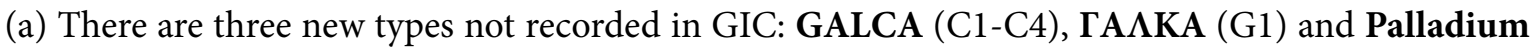

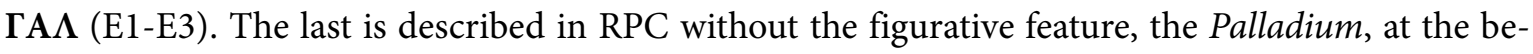
ginning of the legend.

\footnotetext{
${ }^{33}$ Martini 2002, no. 4009.

${ }^{34}$ Martini 2003a, no. 1424.
} 
(b) Five issues, four from the Perinthus mint (RPC 1753, 1758A, 1759, and 1762) and one from Ni caea (RPC 2057) turned out to be variants of the types described in RPC. In all of these it was the direction of Nero's imperial profile that differed from what was reported (cf. Table 1). In 21 cases, the relation between issues recorded in RPC and the countermarks found on them have been revised (cf. Table 2). Two series from Perinthus (RPC 1748, 1762) were found with countermarks that had not been recorded for them (Tables 1-2).

(c) The device preceding the letters of countermark GIC 525, the Palladium ГAAY (D1-D3) type, had been given only a provisional description, taken up in RPC, as "standard?," while in fact it is the mythological feature relating to the cult of Pallas.

(d) There appears to be no denying that a considerable portion of countermarks with the GALBA type struck on sesterces from the imperial mint in Rome must be deemed of modern origin, al though the problem cannot currently be better detailed because of the scarce availability of the known material. This same cannot be said for the other countermarks in the "Galba" name, which appear to be all but immune from counterfeiting save for cases that are altogether sporadic (i.e. 2A.1).

(e) The countermarks analyzed here, as with the manufacture of Latin issues using Roman types, are generically attributed to the Perinthus mint. However, the following attributions seem possible:

1. The GALBA type on imperial sesterces accompanied by the NERCPP type could be attributed to the Moesia area for isolated countermarks, whereas it might be traceable to Nicaea, or to some where in Bithynia in any case, for those found on Nicaea issue.

2. An Asian context, if not Nicomedia itself, would appear a likely attribution for the two types with

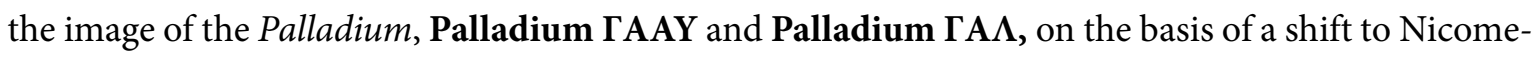
dia for striking Latin- and Greek-legend sesterces with the Neronian scene of the Decursio.

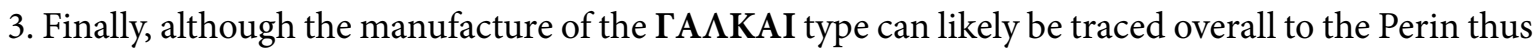
mint, the same cannot be said of the ГА $\mathbf{\Lambda} \mathbf{B A}$ type, which is known from a fair number of dies, whose graphics range widely. The latter might thus be attributed to various output locations, still in the lower Danube area, in all likelihood tied to the main legionary centers in the region. 


\section{Bibliography}

Besombes 2003-2004

Bianchi 2014

Calomino 2016

Campo 1974

Draganov 1991

Fabbricotti 1976

Geranio 2014-

Giard 1970

Giard 1985

GIC

Hahn 1976

Howgego 1982-83

Howgego 1985

[illyricum65]

Kaenel 1984

Kaenel 1984a

Kaenel 1986

Kenyon 1987

Kenyon 1992
P. -A. Besombes, Le depot de 22438 monnaies du gué de SaintLéonard (Mayenne), Trésors Monétaires 21, Paris 2003-2004.

E. Bianchi, Il Senato e la "damnatio memoriae" da Caligola a Domiziano, Politica Antica I (gennaio-dicembre), 2014, 33-54.

D. Calomino, Defacing the Past. Damnation and Desecration in Imperial Rome, London 2016.

M. Campo, El problema de las monedas de imitaciòn de Claudius I en Hispania, Acta Numismática 4, Barcelona 1974, 155-163.

D. Draganov, The Countermarks of Moesia Inferior and Thrace, Klio 73, 495-509, 1991.

E. Fabbricotti, Galba, Roma 1976.

J. Geranio, The Counter Marked Coinage of the Julio Claudians, www.flickr.com/groups, 2014-.

J. -B. Giard, Pouvoir central et liberté locale: les monnayage de bronze de Claude, Revue Numismatique 1970, 33-60.

J. -B. Giard, Les jeux de imitation: fraude ou nécessité?, Quaderni Ticinesi di Numismatica e Antichità Classiche XIV, 1985, 231-238.

C. J. Howgego, Greek Imperial Countermarks. Studies in the Provincial Coinage of the Roman Empire, Royal Numismatic Society Special Publication no. 17, London 1985.

W. Hahn, Die Fundmünzen der römischen Zeit in Österreich. III. Niederösterreich. I. Carnuntum, Wien 1976.

C. J. Howgego, The Behavior and Function of Greek Imperial Countermarks, Israel Numismatic Journal 6-7, 1982-83, 47-58.

C. J. Howgego, Greek Legends and Roman Types: a Neronian Enigma, Schweizerische Münzblätter 140 (November), 1985, 88-92.

illyricum65, I tre rottami della settimana, www.lamoneta.it/topic.

H. -M. von Kaenel, Britannicus, Agrippina Minor und Nero in Thrakien, Schweizerische Numismatik Rundschau 63, 1984, 127166.

H. -M. von Kaenel, Roma - Monete dal Tevere - L'imperatore Claudio I, Bollettino di Numismatica 2-3, 1984, 83-325.

H. -M. von Kaenel, Münzprägung und Münzbildnis des Claudius, Antike Munzen und Geschnittene Steine Band IX., Berlin 1986.

R. Kenyon, The Claudian coinage, Colchester Archaeological Report 4. The coins from excavations in Colchester 1971-9, Colchester 1987, 24-41.

R. F. E. Kenyon, The Copying of Bronze Coins of Claudius in Roman Britain, PhD Thesis, Institute of Archaeology, University College of London, 1992. 
Kos - Šemrov 1995

Mac Dowall 1960

Martini 2002

Martini 2003a

Martini 2003b

Martini 2005

Martini 2017

Nash 1978

RIC

RPC

$\mathrm{RPC}^{\mathrm{S1}}$

$\mathrm{RPC}^{\mathrm{S} 2}$

Savio 2009
P. Kos - A. Šemrov, Roman Imperial Coins and Countermarks on the $1^{\text {st }}$ Century (Augustus Traianus), Situla 33, Ljubljana 1995.

D. W. Mac Dowall, Two Roman Countermarks of A.D. 68, Numismatic Chronicle 20, 1960, 103-112.

R. Martini, Monete romane imperiali contromarcate di bronzo dall'area delle province della Moesia e della Thracia di I secolo d.C. Volume I. Parte 1. Tipologie delle contromarche. Parte 2. Catalogo del materiale (censimento delle monete dalla Moesia e dalla Thracia e delle contromarche di area pannonica). Parte 3. Monete ausiliarie e falsificazioni (Collezioni Numismatiche 2), Milano 2002.

R. Martini, Monete romane imperiali contromarcate di bronzo dall'area delle province della Moesia e della Thracia di I secolo d.C. Volume 2. Parte 1. cronologia relativa alle contromarche. Parte 2. Catalogo del materiale (censimento delle monete dalla Moesia e dalla Thracia e delle contromarche di area pannonica). Parte 3. Tecniche di produzione delle monete e delle contromarche. Parte 4. Tipologie delle contromarche. Addenda I (Collezioni Numismatiche 3), Milano 2003.

R. Martini, Collezione Pangerl. Contromarche imperiali romane (Augustus - Vespasianus) (Nomismata 6), Milano 2003.

R. Martini, Monete imperiali contromarcate. Nota II. Sesterzio di Tiberius per il Divus Augustus con contromarca NCAPR, Quaderno di Studi LXVIII (marzo-aprile), 2005, 1-39.

R. Martini, Countermarks with "god standing" and "spiked helmet" types struck in Sicily on Rome-minted Augustan sesterces from the Moesia-Thrace region: New evidence of legionary movements in Julian-Claudian times, in: D. Boteva (ed.), Ex nummis lux. Studies in Ancient Numismatics in Honour of Dimitad Draganov, Sofia 2017, 235-260.

D. Nash, Plus ça change... ! Currency in Central Gaul from Iulius Caesar to Nero, Scripta Nummaria Romana. Essays presented to Humphrey Sutherland, London 1978, 12-31.

C. H. V. Sutherland, The Roman Imperial Coinage. Volume I (Revised edition). 31 BC - AD 69, London 1984.

A. Burnett - M. Amandry - P. P. Ripollès, Roman Provincial Coinage. Volume I. From the death of Caesar to the death of Vitellius (44 BC - AD 69), London-Paris 1992.

A. Burnett - M. Amandry - P. P. Ripollès, Roman Provincial Coinage. Supplemet I, London-Paris 1998.

A. Burnett - M. Amandry - P. P. Ripollès, I. Carradine, Roman Provincial Coinage. Supplemet 2, www.uv.es/ ripolles/rpc_2 (2006).

A. Savio, L'effetto della damnatio memoriae sulle monete dell'alto 
Schönert 1965

Smith 2000

Varner 2004

Vladimirova-Aladžova 1986

Vladimirova-Aladžova 1999
Impero, Valori e disvalori simbolici delle monete. I. Trenta denari di Giuda, Milano 2009, 105-117.

E. Schönert, Die Münzprägung von Perinthos, Deutsche Akademie der Wissenschaften zu Berlin, 1965.

D. R. Smith, The DECVRSIO sestertius of Nero and the lusus Troiae, Numismatic Chronicle 160, 2000, 282-289.

E. R. Varner, Mutilation and Transformation: Damnatio Memoriae and Roman Imperial Portraiture, Leiden 2004.

D. Vladimirova-Aladžova, A Countermark of Galba on coin of Nero [bulgarian text], Numizmatika 20.2, 1986, 36-38.

D. Vladimirova-Aladžova, Counter-marked Roman coins from Lower Danube, Macedonian Numismatic Journal 3, 1999, 45-49. 
Table 1. Cmks

\begin{tabular}{|c|c|c|c|c|c|c|c|c|c|}
\hline $\mathrm{cmk}$ & Roma & $\begin{array}{l}\text { Perinthus } \\
\text { (G) }\end{array}$ & RPC & $\begin{array}{l}\text { Perinthus } \\
\text { (L) }\end{array}$ & RPC & Nicaea & RPC & Nicomedia & RPC \\
\hline GACPP (GIC ---) & $\bullet$ & & & & & & & & \\
\hline GALBA (GIC 591) & $\bullet$ & & & & & $\bullet$ & * & & \\
\hline GALCA (GIC ---) & $\bullet$ & & & $\bullet$ & --- & $\bullet$ & --- & & \\
\hline $\begin{array}{l}\text { Palladium } \\
\text { (GIC 525) }\end{array}$ & & & & & & & & $\bullet$ & * \\
\hline $\begin{array}{l}\text { Palladium } \\
(\text { GIC ---) }\end{array}$ & & & & $\bullet$ & $(?)$ & & & & \\
\hline ГААВА (GIC 526) & & $\bullet$ & * & $\bullet$ & * & $\bullet$ & --- & $\bullet$ & --- \\
\hline ГАМКА (GIC ---) & & & & $\bullet$ & -- & & & & \\
\hline ГА $\mathbf{K A I}$ (GIC 527) & $\bullet$ & $\bullet$ & * & $\bullet$ & * & & & & \\
\hline
\end{tabular}

Table 2. Mints

\begin{tabular}{|c|c|c|c|c|c|c|c|c|}
\hline mint & GACPP & GALBA & GALCA & $\begin{array}{l}\text { Palladium } \\
\text { ГAAY }\end{array}$ & 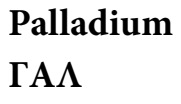 & ГААВА & ГААКА & ГА $\Lambda$ КАІ \\
\hline Roma & 0 & 0 & 0 & & & & & 0 \\
\hline $\begin{array}{l}\text { Perinthus } \\
\text { (L) }\end{array}$ & & & 0 & & 0 & 0 & 0 & 0 \\
\hline $\begin{array}{l}\text { Perinthus } \\
(\mathrm{G})\end{array}$ & & & & & & 0 & & $\bullet$ \\
\hline Nicaea & & $\bullet$ & 0 & & & 0 & & \\
\hline Nicomedia & & & & 0 & 0 & 0 & & \\
\hline
\end{tabular}

Table 3. Cmks / issues

\begin{tabular}{|l|l|l|l|l|l|l|l|}
\hline cmk & $\begin{array}{l}\text { sestertius } \\
(\mathrm{L})\end{array}$ & $\begin{array}{l}\text { sestertius } \\
(\mathrm{G})\end{array}$ & $\begin{array}{l}\text { dupondius } \\
(\mathrm{L})\end{array}$ & $\begin{array}{l}\text { dupondius } \\
(\mathrm{G})\end{array}$ & $\begin{array}{l}\text { as } \\
(\mathrm{L})\end{array}$ & $\begin{array}{l}\text { as } \\
(\mathrm{G})\end{array}$ & $\begin{array}{l}\text { semis } \\
(\mathrm{G})\end{array}$ \\
\hline GACPP (GIC ---) & $\bullet$ & & & & & & \\
\hline GALBA (CIG 591) & $\bullet$ & $\bullet$ & & $\bullet$ & & $\bullet$ & \\
\hline
\end{tabular}




\begin{tabular}{|c|c|c|c|c|c|c|c|}
\hline GALCA (CIG ---) & $\bullet$ & $\bullet$ & 0 & 0 & 0 & & \\
\hline $\begin{array}{l}\text { Palladium ГAAY (GIC } \\
525)\end{array}$ & & & & & $\bullet$ & 0 & \\
\hline Palladium ГА $\Lambda$ (GIC ---) & $\bullet$ & $\bullet$ & 0 & & & & $\bullet$ \\
\hline ГААВА (GIC 526) & $\bullet$ & $\bullet$ & 0 & 0 & 0 & 0 & \\
\hline ГА $\mathbf{K A}$ (GIC ---) & $\bullet$ & & 0 & & & & \\
\hline ГА $\mathbf{K A I}$ (GIC 527) & 0 & 0 & 0 & & 0 & 0 & \\
\hline
\end{tabular}

Table 1. MINTS

\begin{tabular}{|c|c|c|c|c|}
\hline Type & RIC & $\mathrm{Cmk}$ & \multicolumn{2}{|l|}{ GIC } \\
\hline \multicolumn{5}{|l|}{ ROMA } \\
\hline sestertius & $51,54,62$ & GALBA & \multicolumn{2}{|l|}{591} \\
\hline sestertius & 99 & \multicolumn{3}{|c|}{ GACPP + GALBA [x2] --- / 591} \\
\hline sestertius & $93,99,102$ & GALBA & \multicolumn{2}{|l|}{591} \\
\hline sestertius & 96,112 & GALCA & \multicolumn{2}{|l|}{---} \\
\hline \multicolumn{5}{|c|}{ LUGDUNUM } \\
\hline sestertius & 391 & \multicolumn{3}{|l|}{ ГААКАI } \\
\hline & RPC & & GIC & $\mathrm{RPC}(\mathrm{Cmks})$ \\
\hline \multicolumn{5}{|c|}{ PERINTHUS } \\
\hline \multicolumn{5}{|c|}{ Latin legends } \\
\hline sestertius & 1758 & GALCA & --- & $\Gamma А \Lambda \mathrm{KAI}$ \\
\hline sestertius & $1758 \mathrm{~A}$ & GALCA & --- & Standard? ГААY \\
\hline as & 1760 & GALCA & --- & $\Gamma \mathrm{A} \Lambda \mathrm{BA}$ \\
\hline sestertius & $1758 \mathrm{~A}$ & Palladium ГА $\Lambda$ & --- & Standard? ГААY \\
\hline sestertius & 1758 & $\Gamma A \Lambda \mathbf{B A}$ & 526 & $\Gamma А \Lambda \mathrm{KAI}$ \\
\hline dupondius & 1759 & $\Gamma A \Lambda \mathbf{B A}$ & 526 & ГА $\Lambda$ ВА \\
\hline dupondius & 1759var. & $Г А \Lambda \mathrm{BA}$ & 526 & Standard? ГААY \\
\hline as & 1760 & $Г А \Lambda В A$ & 526 & $Г А \Lambda \mathrm{BA}$ \\
\hline as & 1761 & $\Gamma A \Lambda \mathbf{B A}$ & 526 & $Г А \Lambda В А$ \\
\hline as & $1761 \mathrm{~A}$ & $\Gamma A \Lambda \mathbf{B A}$ & 526 & $Г А \Lambda В А$ \\
\hline as & 1762 & ГААВА & 526 & - \\
\hline
\end{tabular}




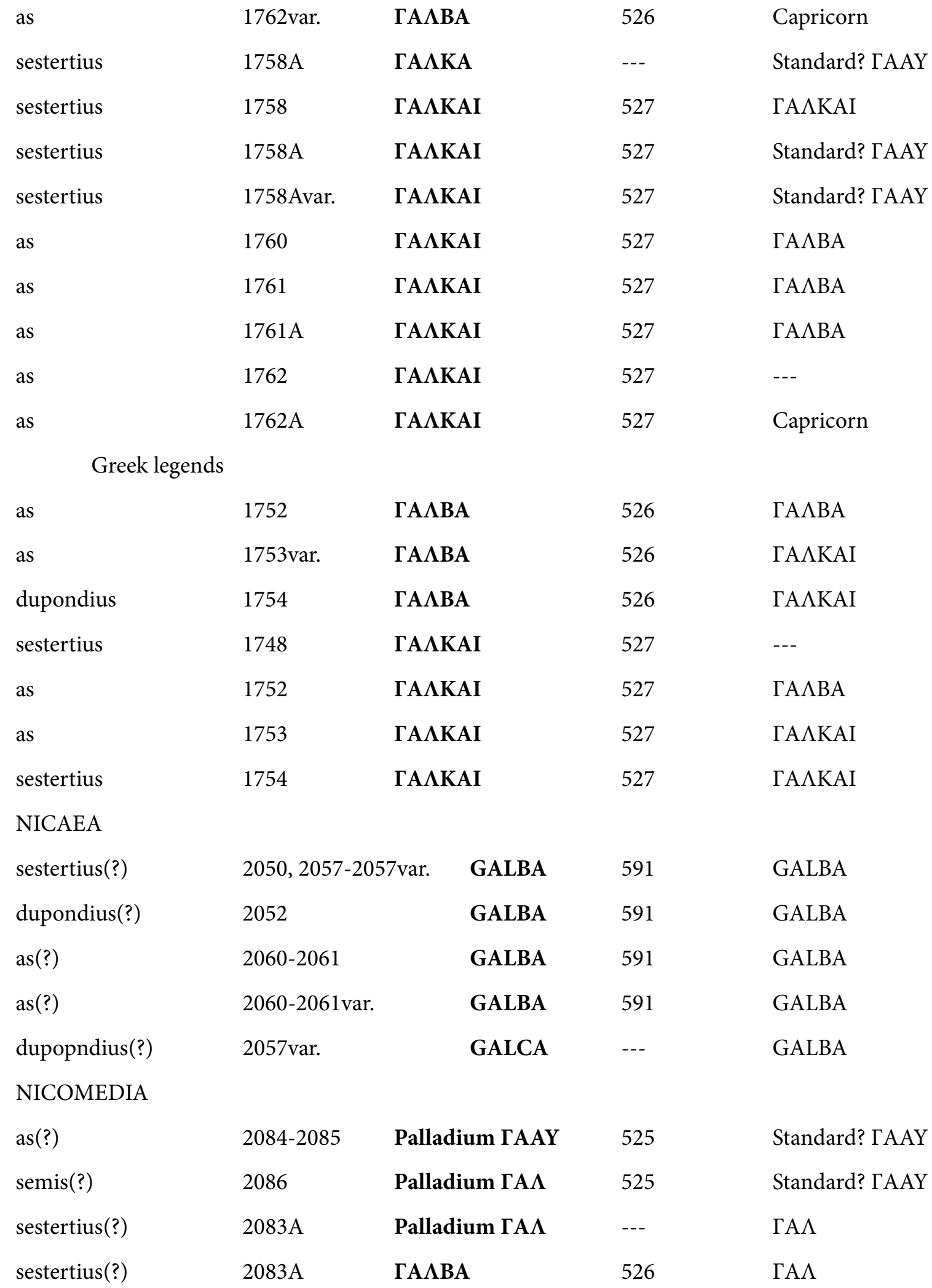


Table 2. COUNTERMARKS

Mint Latin Greek RPC RPC (other Cmks)

GACPP

Roma

sestertius

RIC 99

GALBA (GIC 591)

Roma

sestertius

RIC 62

Roma sestertius

RIC 93, 99, 102

Nicaea sestertius(?)

RPC 205

GALBA

Nicaea dupondius(?)

RPC 2052

GALBA

Nicaea dupondius(?)

RPC 2057-2057var. GALBA

Nicaea as(?)

RPC 2060-2061

GALBA

Nicaea

as(?)

RPC 2060-2061var.

GALBA

GALCA (GIC ---)

$\begin{array}{ll}\text { Roma } & \text { sestertius } \\ \text { Perinthus } & \text { sestertius } \\ \text { Perinthus } & \text { sestertius } \\ \text { Perinthus } & \text { as } \\ \text { Nicaea } & \text { sestertius(?) }\end{array}$

RIC 96,112

RPC 1758

$\Gamma \mathrm{A} \Lambda \mathrm{KAI}$

RPC 1758A

--- $\quad$ Standard? TAAY

RPC 1760

$\Gamma \mathrm{A} \Lambda \mathrm{BA}$

RPC 2057var.

GALBA

Palladium ГAAY (GIC 525)

Nicomedia as(?)

RPC 2084-2085

Standard? ГAAY

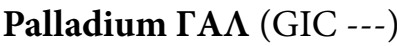

Perinthus sestertius

RPC 1758A

Standard? ГAAY

Nicomedia sestertius(?)

RPC 2081A

$\Gamma \mathrm{A} \Lambda$

Nicomedia semis(?)

RPC 2086

Standard? ГAAY

ГААВА (GIC 526)

Perinthus as

RPC 1752

$Г А \Lambda \mathrm{BA}$

Perinthus as

RPC 1753var.

$Г А \Lambda \mathrm{BA}$

Perinthus dupondius

RPC 1754

$\Gamma A \Lambda \mathrm{KAI}$

Perinthus sestertius

RPC 1758

$\Gamma A \Lambda \mathrm{KAI}$

Perinthus dupondius

RPC 1759

$\Gamma A \Lambda \mathrm{KAI}$

Perinthus dupondius

RPC 1759var.

Standards? ГAAY

Perinthus as

RPC 1760-1761

$Г \mathrm{~A} \Lambda \mathrm{BA}$ 


\begin{tabular}{|c|c|c|c|c|}
\hline Perinthus & as & RPC 1761A & $\Gamma \mathrm{A} \Lambda \mathrm{BA}$ & \\
\hline Perinthus & as & RPC 1762 & --- & --- \\
\hline Perinthus & as & RPC 1762Avar. & --- & Capricorn \\
\hline Nicaea & dupondius(?) & RPC 2060 & --- & GALBA \\
\hline Nicomedia & sestertius(?) & RPC 2083A & --- & ГА $\Lambda$ \\
\hline \multicolumn{5}{|c|}{ ГАМКА (GIC ---) } \\
\hline Perinthus & sestertius & RPC 1758A & --- & Standard? ГАAY \\
\hline \multicolumn{5}{|c|}{ ГАМКАI (GIC 527) } \\
\hline Lugdunum & sestertius & RIC 391 & & \\
\hline Perinthus & sestertius & RPC 1748 & --- & --- \\
\hline Perinthus & as & RPC 1752 & --- & $Г А \Lambda \mathrm{BA}$ \\
\hline Perinthus & as & RPC 1753 & $\Gamma A \Lambda \mathrm{KAI}$ & \\
\hline Perinthus & sestertius & RPC 1754 & $\Gamma A \Lambda \mathrm{KAI}$ & \\
\hline Perinthus & sestertius & RPC 1758 & $\Gamma A \Lambda \mathrm{KAI}$ & \\
\hline Perinthus & sestertius & RPC 1758A & --- & Standards? ГААY \\
\hline Perinthus & sestertius & RPC 1758Avar. & --- & Standard? ГАAY \\
\hline Perinthus & as & RPC 1760-1761 & --- & $\Gamma \mathrm{A} \Lambda \mathrm{BA}$ \\
\hline Perinthus & as & RPC 1761A & --- & $Г А \Lambda \mathrm{BA}$ \\
\hline Perinthus & as & RPC 1762 & --- & --- \\
\hline Perinthus & as & RPC 1762A & --- & Capricorn \\
\hline
\end{tabular}




\section{Roma İmparatorluk ve Eyalet Sikkeleri Üzerinde Bulunan “Galba” İsimli Kontrmarklar: Kontrmarklar Üzerine Düşünceler ve Yerli Bronz Sikkelerin Pannonia (?), Moesia, Thrakia ve Küçük Asya'daki (?) Sirkülasyonu Özet}

$\mathrm{Bu}$ makale, bir yandan RPC-I'in yayınlanmasından itibaren tanımlanan tipleri kataloglayarak, öte yandan aşağı Tuna sınırı ve Pontus et Bithynia eyaleti etrafında kontrmark işlemlerinin kurulduğu yerde, Galba'nın emperyal politikasıyla uyum içindeki bir faaliyet olan sosyal bağlamı tanımlayarak, bilinen tiplerin sırasını doğrulamak, düzeltmek ve geliştirmek amacıyla ya komple yazılmış ya da kısaltılmış şekilde "Galba" ismini kullanan Latince ve Yunanca lejantlı sekiz farklı imparatorluk kontrmarkını araştırmaktadır. Bu makale, kontrmarkların basıldığı bölgeler ve basılmış sikkelerin dağılımı ile ilgili soruları aralarından seçip bu sorunlara son zamanlarda belgelenen tiplerle alakalı önemli yeni kanıtları göz önüne getiren kısa bir tartışma sunmaktadır. Şimdiye kadar tam anlamıyla incelenmemiş olan imparatorluk dönemi sikkelerinin hem basımı hem de sirkülasyonunun belirgin özellikleri resmedilmiştir. Özel önem elbette eyaletlerin idari yönetimi ile birlikte yakın bir ilişki içinde giden Roma lejyon yönetiminin parayla ilgili operasyonlarına verilmiştir. İki tane kontrmarkın okunuşu GIC kataloğuyla karşılaştırılarak düzeltilmiştir. Ayrıca üç tane yeni kontrmark tipi tanımlanmıştır. Son olarak kataloğun bir bölümü modern sahteciliğe ayrılmıştır. Bu tipler uygun belgelendirme yokluğu sahtekârlığın biçimini tespit etmeyi imkânsız kıldığından oldukça sık bulunmaktadır.

Anahtar Sözcükler: Kont(e)rmark; Galba; sikke; sikke sirkülasyonu; sikke sahtekârlığı.

\section{Countermarks in the Name "Galba" on Roman Imperial and Provincial Coinages: Considerations on the Countermarks and the Circulation of Local Bronze Coins in Pannonia (?), Moesia, Thrace and Asia Minor (?) Abstract}

This article investigates the eight different imperial countermarks with Latin and Greek legends that use the name "Galba," either spelled out or abbreviated, in order to verify, correct, and update the sequence of known types, cataloguing specimens identified since publication of RPC-I, on the one hand, and, on the other, describing the social context where the countermarking operation was set up around the lower Danube limes and the province of Pontus et Bithynia, activity in keeping with the Galba's imperial policy. It singles out questions over the areas where the countermarks were struck and the coinage distributed, offering concise discussion of these problems that takes in to account important new evidence from recently documented specimens. Certain facets of both the minting and circulation of imperial bronze coinage that had not been properly assessed hereto fore are limned. Special attention is paid to the moneying operations of the Roman Legionary ad ministration, run, of course, in close coordination with the provincial administrative apparatus. The reading of two countermarks has been corrected, compared to the GIC catalog. Three new countermark types have also been identified. Finally, the catalog devotes a section to modern forge ries, specimens found rather often, whose lack of proper documentation may make it impossible to ascertain the nature of the counterfeiting.

Keywords: Countermarks; Galba; Coinages; Circulation of coinages; Coin forgeries. 


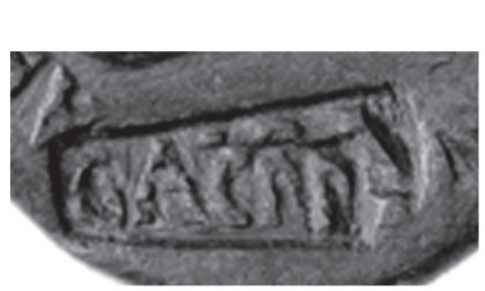

A1.1

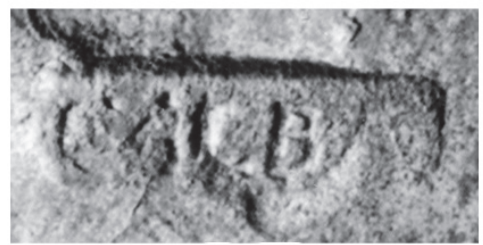

B5.6

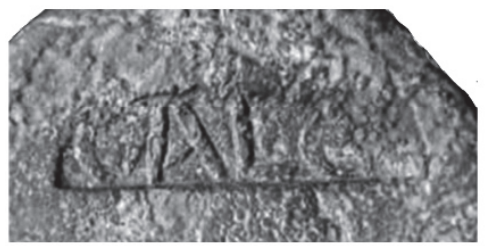

C2.1

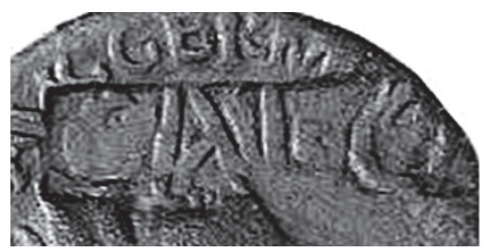

C4.1

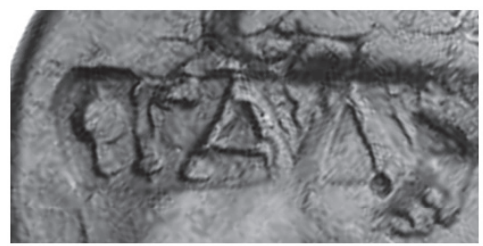

E1.1

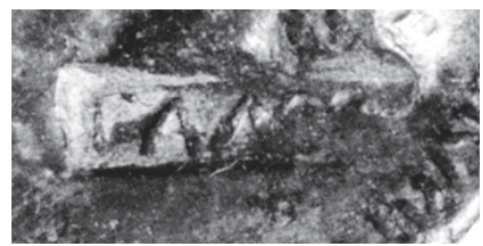

F5.2

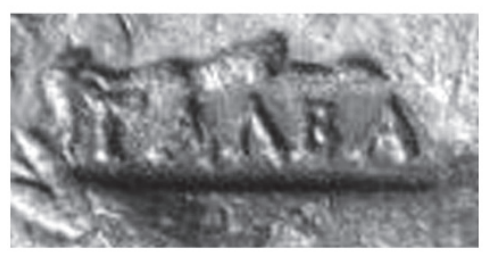

F7.8

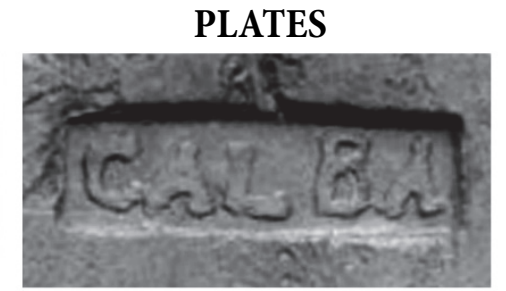

B2.2

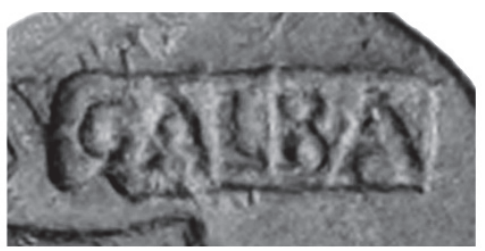

B8.1

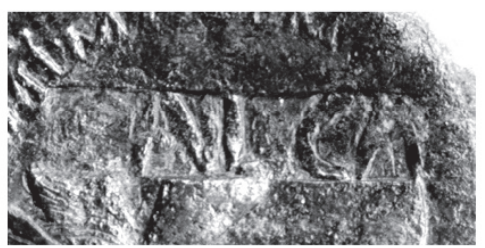

C3.1

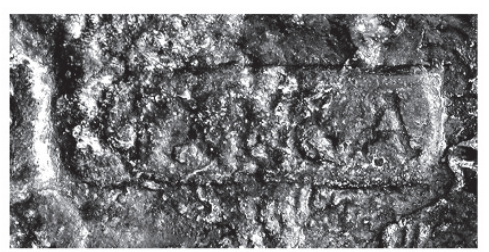

C5.1

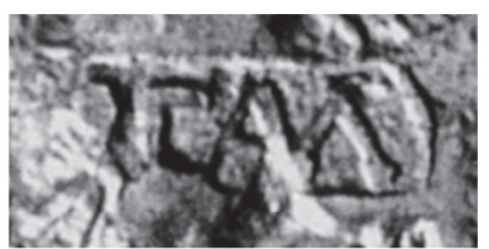

$\mathrm{E} 2$

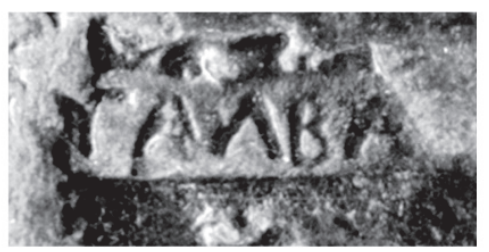

F7.1

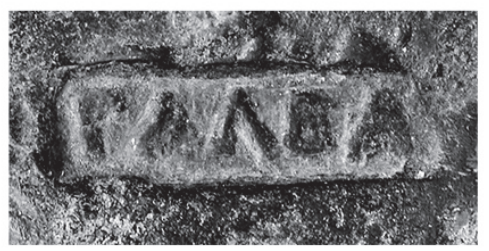

F10.4

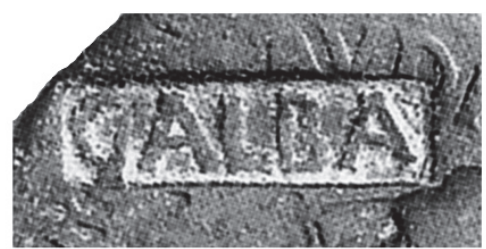

B5.2

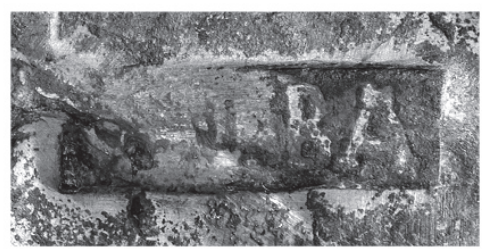

B14.1

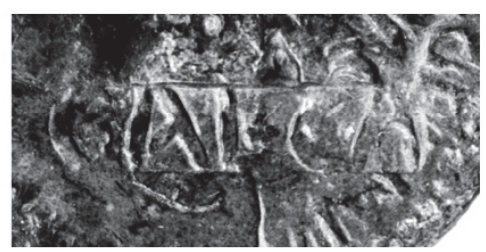

C3.2

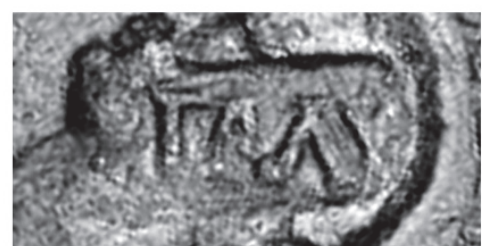

D1.1

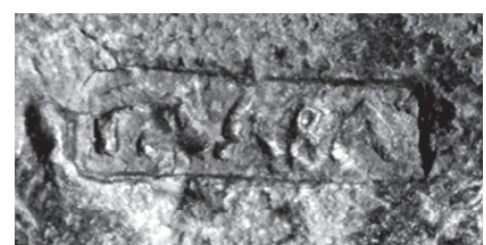

F5.1

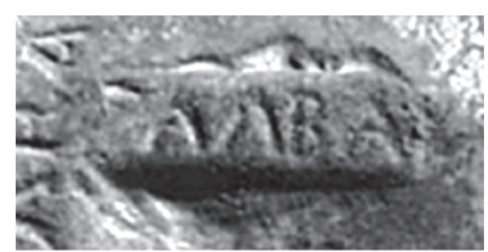

F7.4

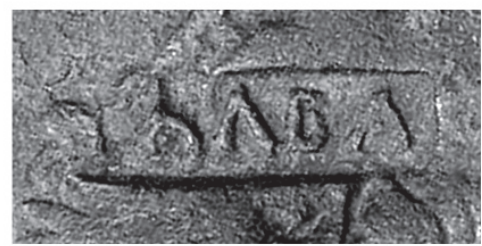

F10.5 


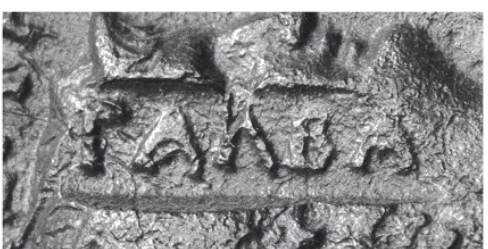

F12.2

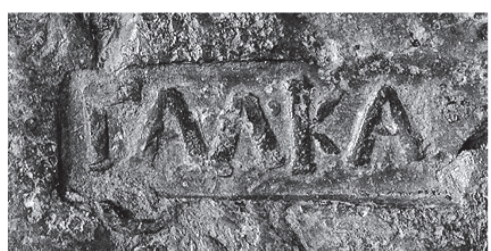

G1.1

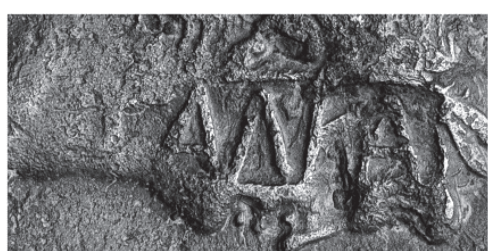

G1.2

$\Gamma A \Lambda \mathrm{KAI}$ (large size)

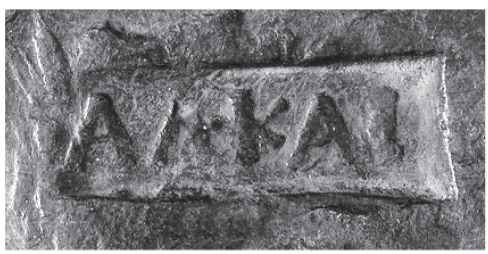

H2. 2

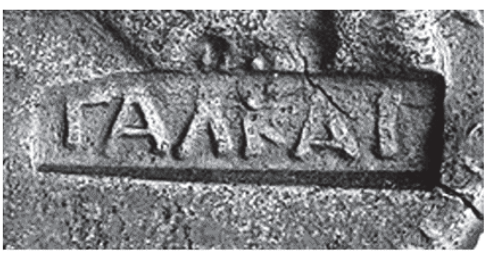

H7.9

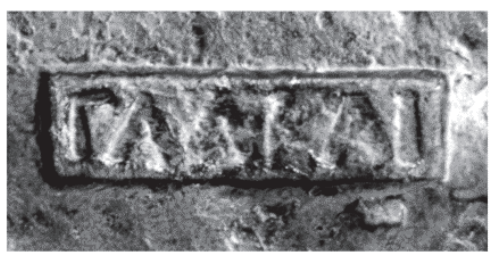

H4. 2

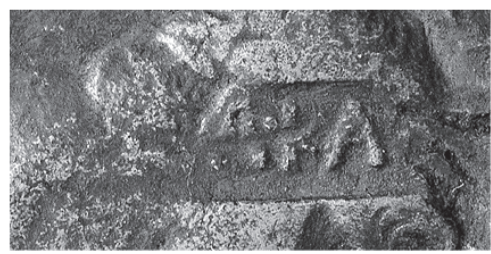

H9.2

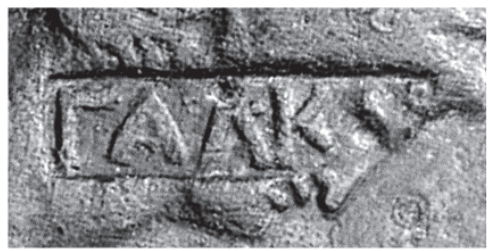

H6.6

$\Gamma \mathrm{A} \Lambda \mathrm{KAI}$ (uncertain size)

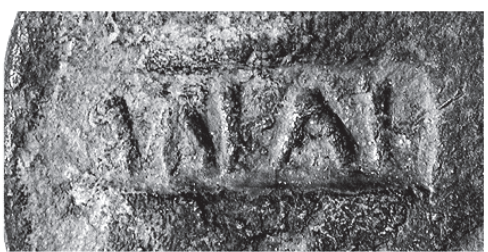

H3.1

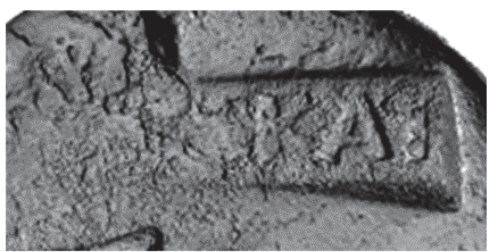

H6.7

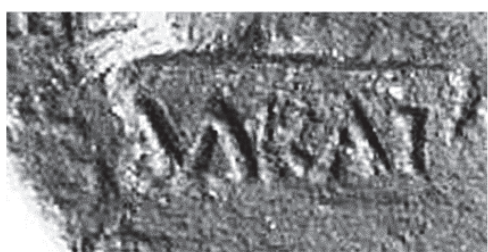

H10.3

$\Gamma A \Lambda \mathrm{KAI}$ (small size)

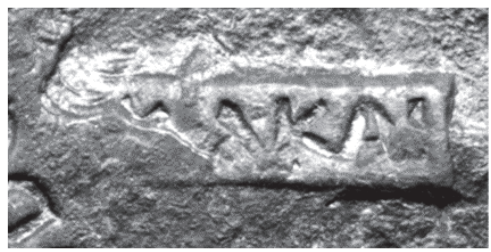

H1.1

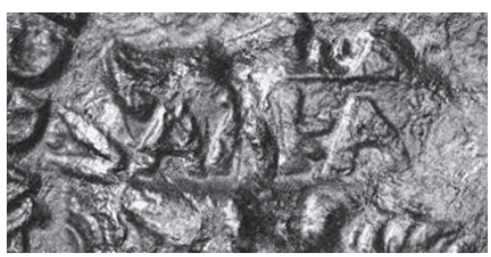

H6.10

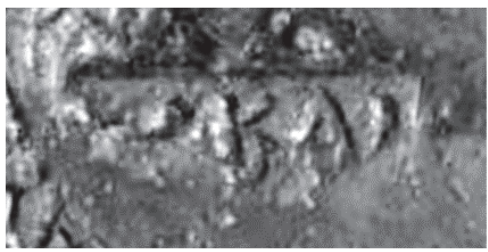

H5.4

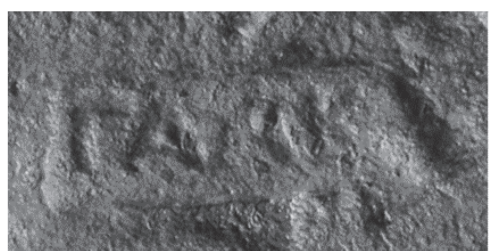

H7.8

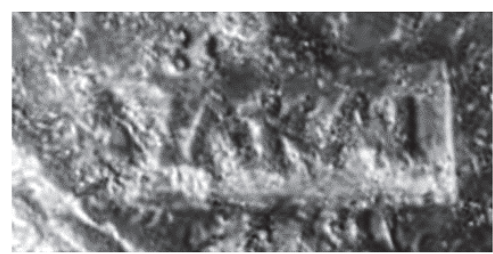

H6.4

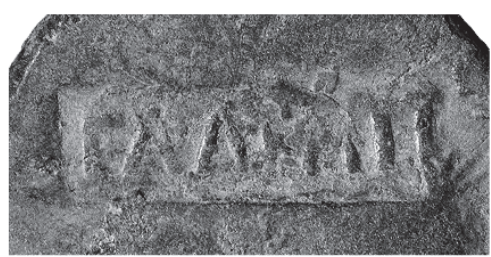

H10.1 
Uncertain

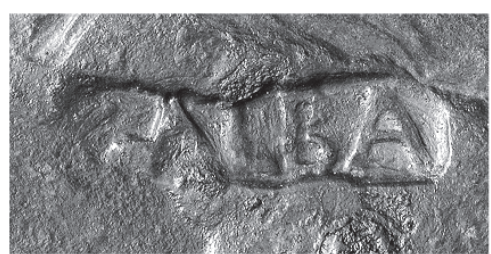

B8.2

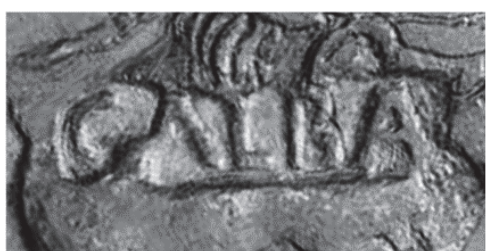

B14.2

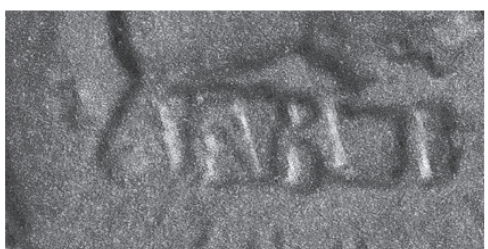

H7.6

Modern forgeries

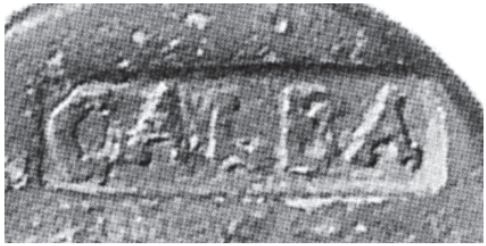

1 A. 1

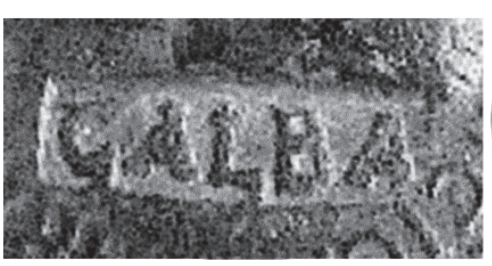

1D. 1

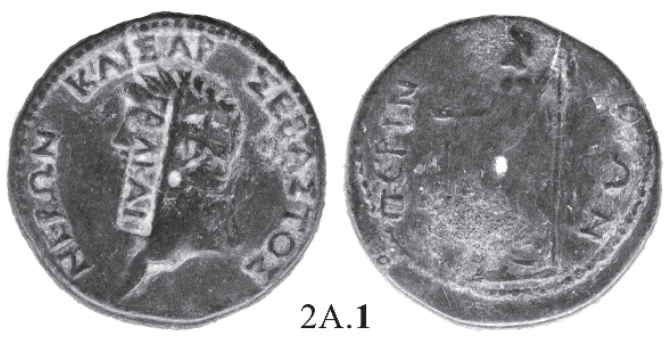

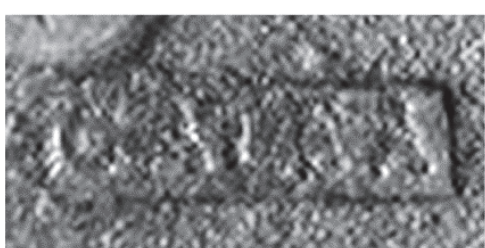

B10.10

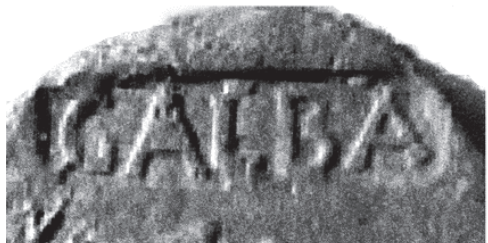

B15.4

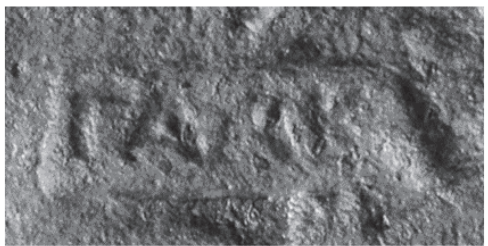

H7.8

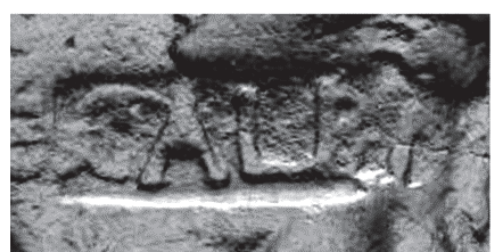

B13.1

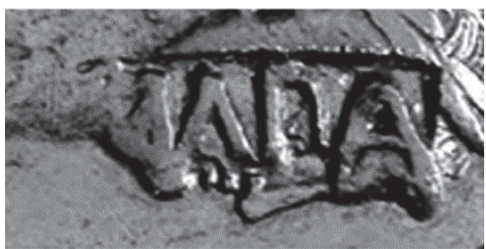

F13.1

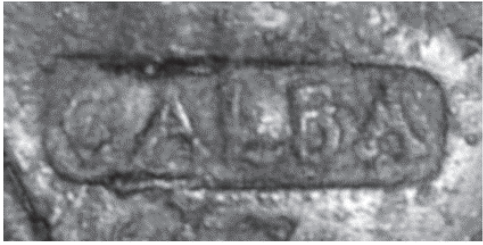

1B.1

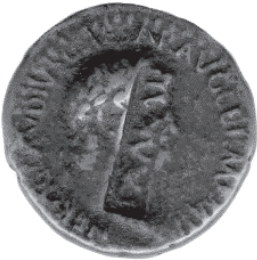

2B.1

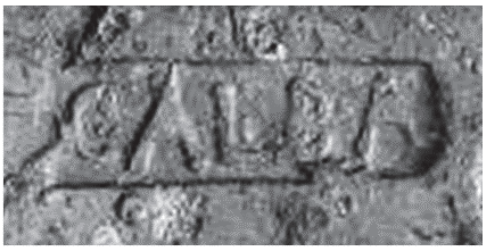

$1 \mathrm{C} .1$

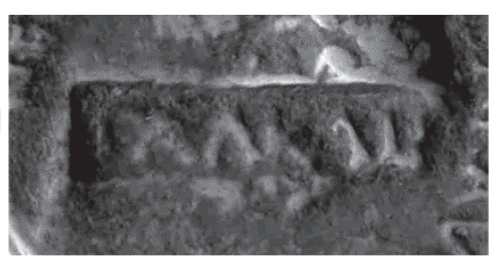

2B.1

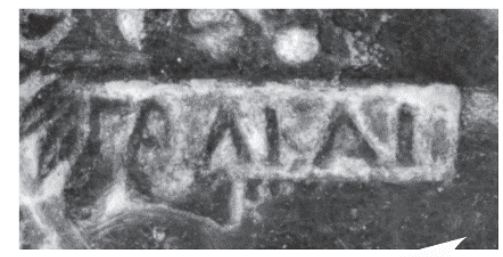

2A.1 
Damnatio Memoriae

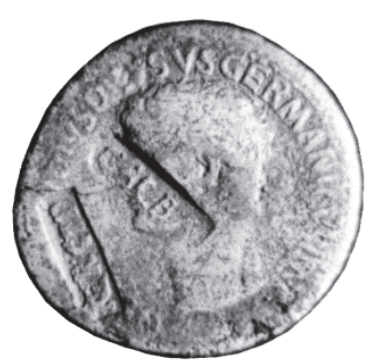

B5.1

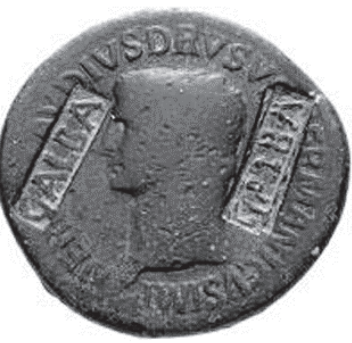

B5.2

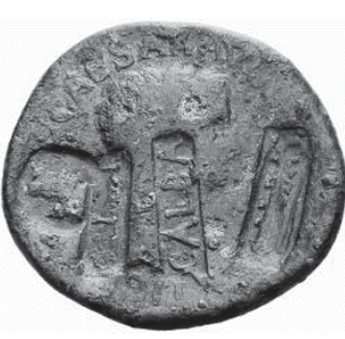

B8 5

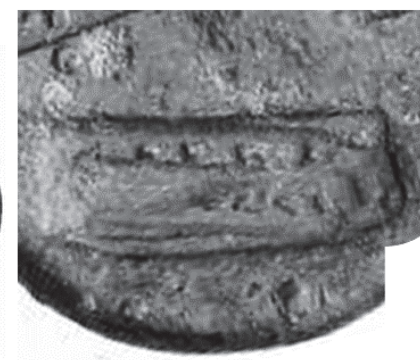

B8.5 (erased GALBA)

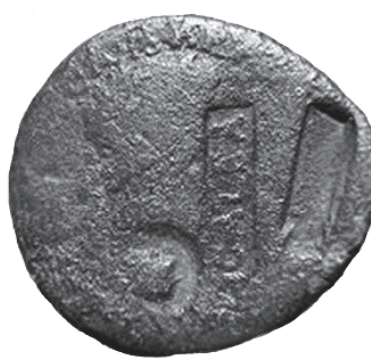

$\mathrm{B} 10.10$

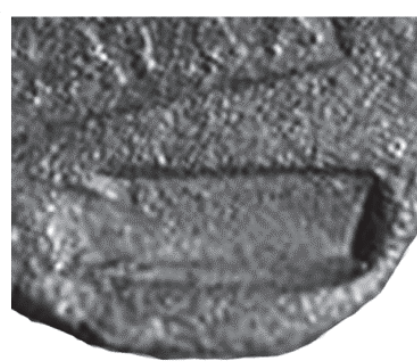

B10.10 (erased GALBA?)

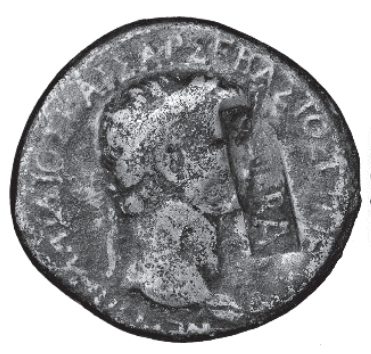

B14.1

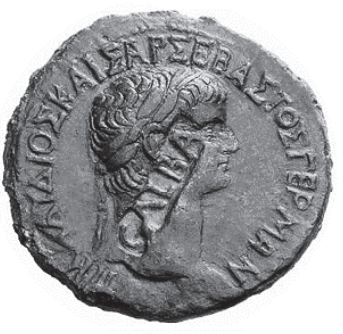

B14.2

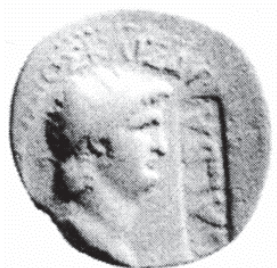

B16.1

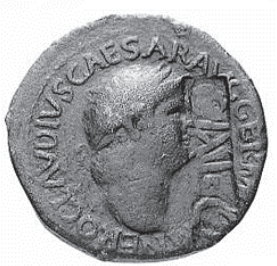

C4.1

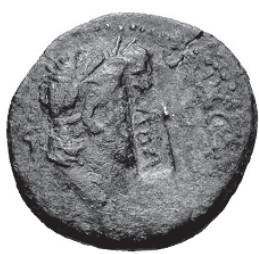

F1.6

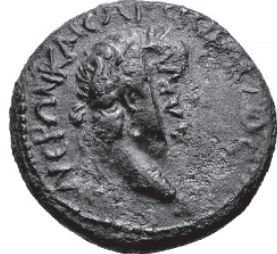

F1.7

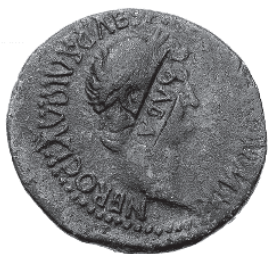

F10.3

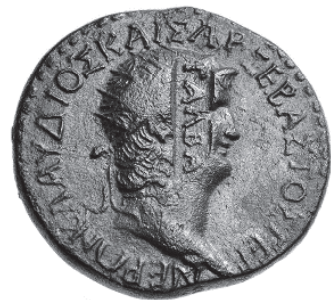

F12.2

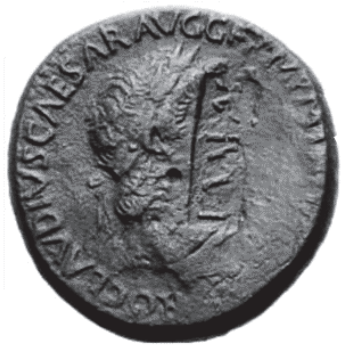

H6.12

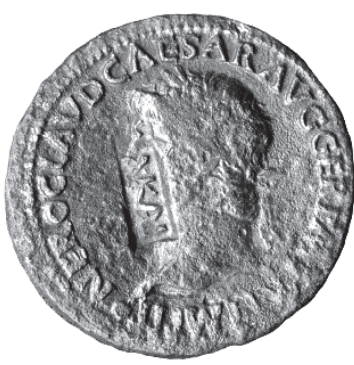

H1. 1

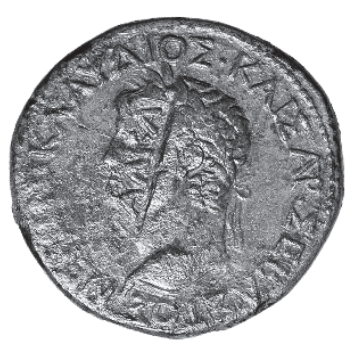

H5.1

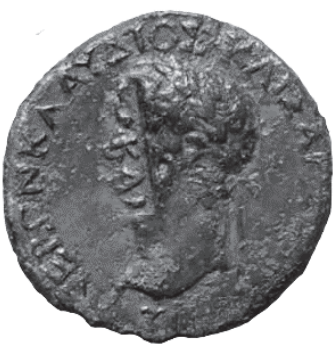

H5.4

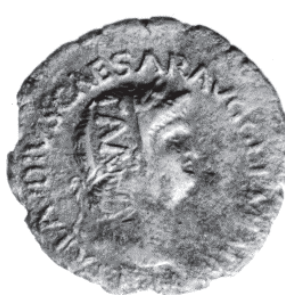

H9.1

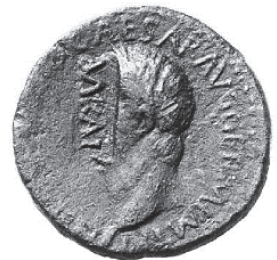

H10.3

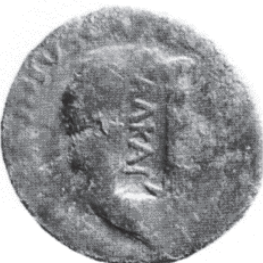

H14.1 
Enlargments

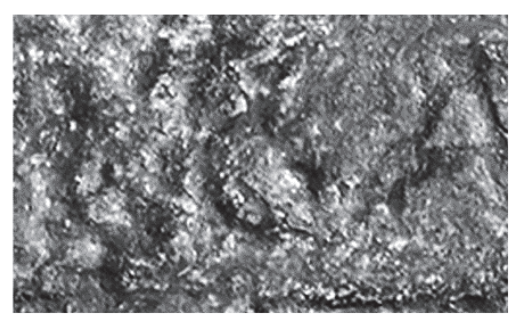

C5.1

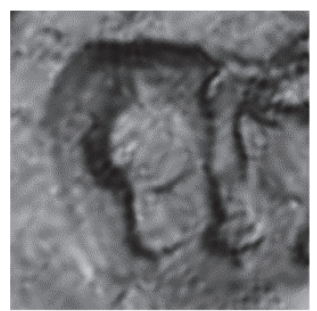

E1.1

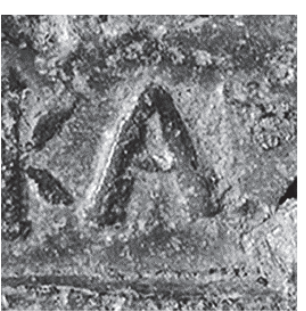

G1.1

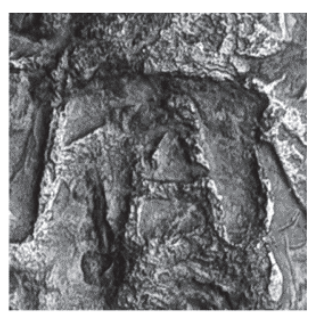

G1.2

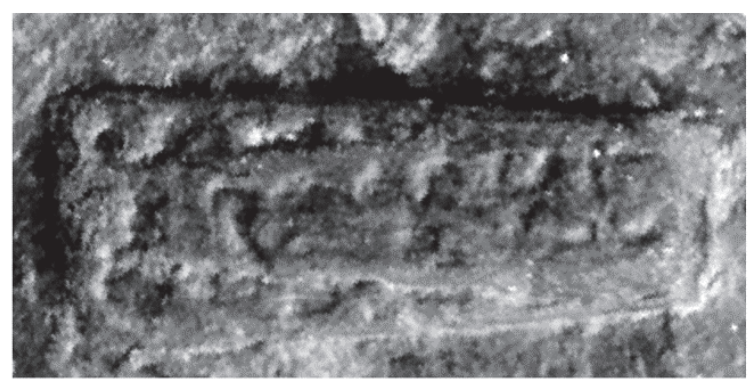

B5.3

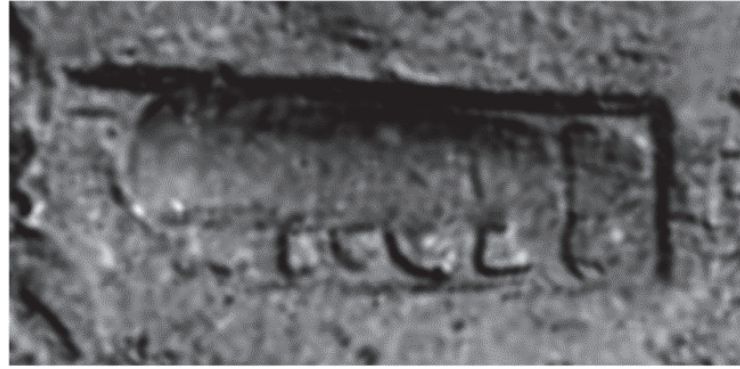

B8.3

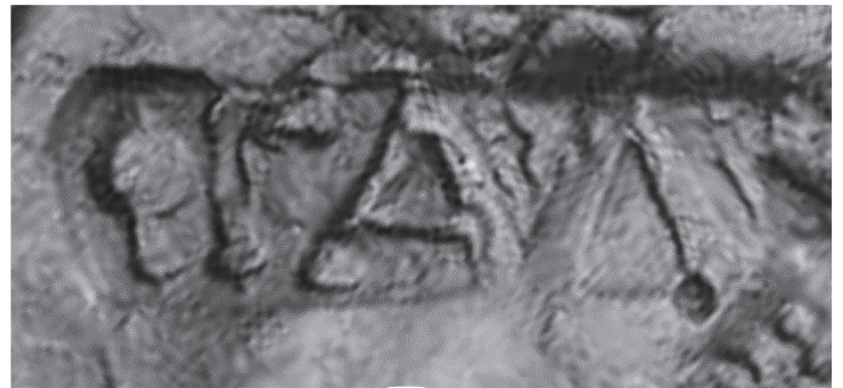

$\mathrm{A}(\mathrm{E} 1.1)$

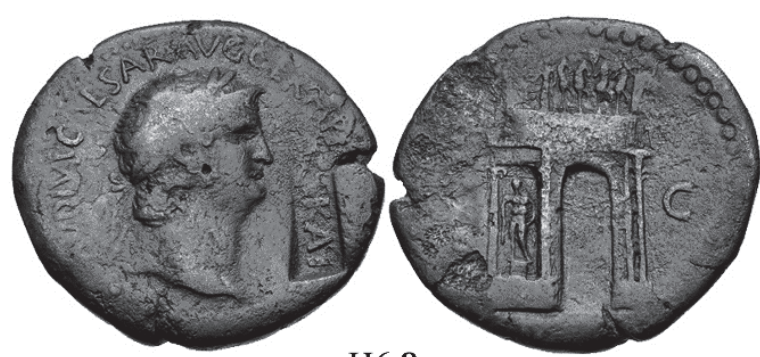

H6.8

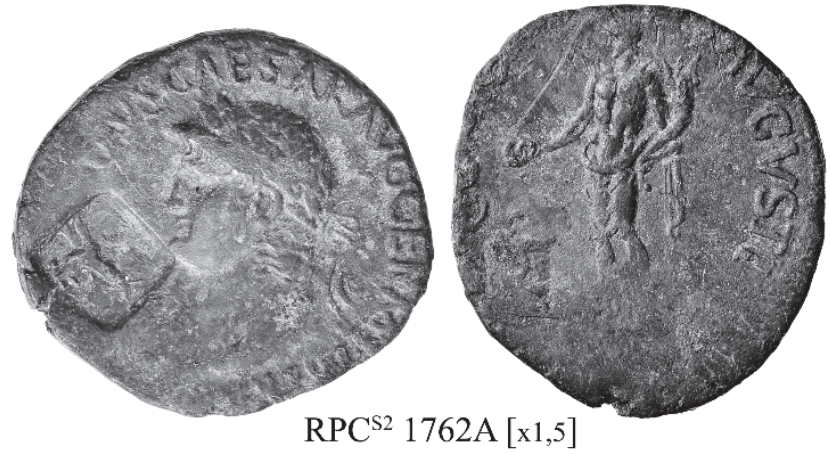

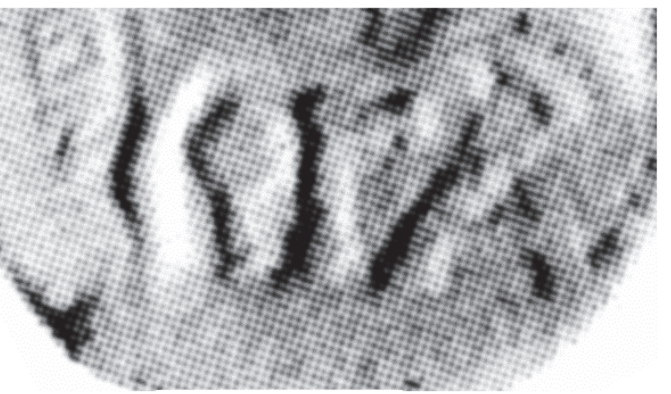

B (E3)

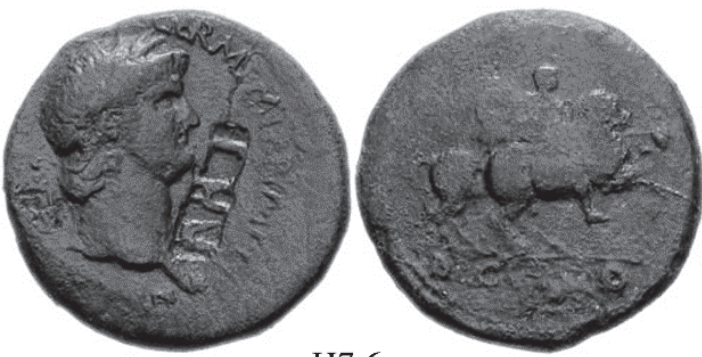

H7.6 